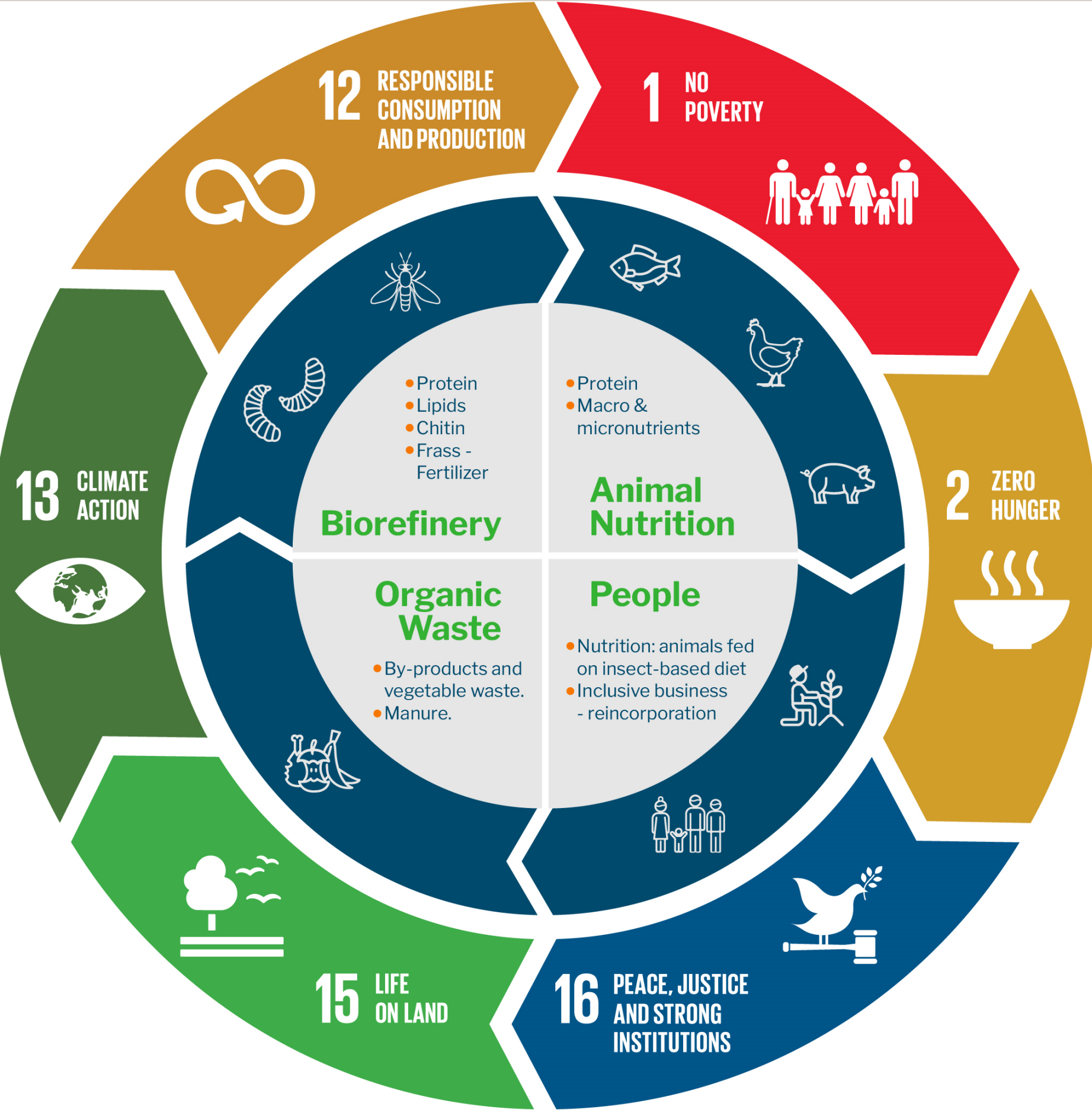

Fighting rural poverty in Colombia:

Circular agriculture by using insects as feed in aquaculture

Karol B. Barragán-Fonseca, Adriana P. Muñoz-Ramírez, Nils Mc Cune,

Julián Pineda, Marcel Dicke \& Julián Cortés

Public

Report 1353

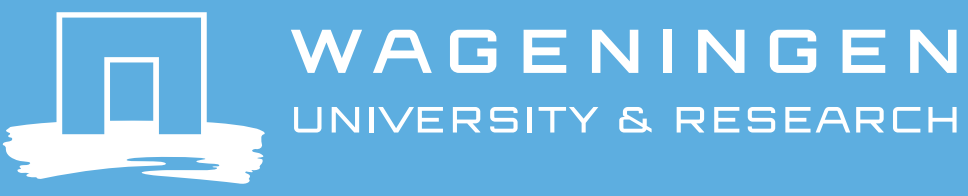





\section{Fighting rural poverty in Colombia: Circular agriculture by using insects as feed in aquaculture}

Karol B. Barragán-Fonseca, Adriana P. Muñoz-Ramírez, Nils Mc Cune, Julián Pineda, Marcel Dicke \& Julián Cortés

This research was carried out by Wageningen Livestock Research and the Universidad Nacional de Colombia subsidised by the Dutch Ministry of Agriculture, Nature and Food Quality, within the framework of Policy Support Research theme 'Veilige en duurzame primaire productie' (project number BO-43-111-021) KD-2021-010.

Wageningen Livestock Research

Wageningen, January 2022

Public

Report 1353 
Barragan Fonseca, K., A. Muñoz-Ramírez, N. Mc Cune, J. Pineda, M. Dicke, J. Cortés-Urquijo, 2021. Fighting rural poverty in Colombia: Circular agriculture by using insects as feed in aquaculture. Wageningen Livestock Research, Report 1353.

This report presents the results of a research project that investigated the opportunities to use insects produced on organic residual streams as novel protein component of fish feed to develop a circular agriculture that is environmentally, economically and socially sustainable. This was done in response to a question of the Dutch Ministry of Agriculture.

This report can be downloaded for free at https://doi.org/10.18174/561878 or at www.wur.nl/livestock-research (under Wageningen Livestock Research publications).

\section{(cc) BY-NC}

This work is licensed under a Creative Commons Attribution-Non Commercial 4.0 International License.

(C) Wageningen Livestock Research, part of Stichting Wageningen Research, 2022

The user may reproduce, distribute and share this work and make derivative works from it. Material by third parties which is used in the work and which are subject to intellectual property rights may not be used without prior permission from the relevant third party. The user must attribute the work by stating the name indicated by the author or licensor but may not do this in such a way as to create the impression that the author/licensor endorses the use of the work or the work of the user. The user may not use the work for commercial purposes.

Wageningen Livestock Research accepts no liability for any damage resulting from the use of the results of this study or the application of the advice contained in it.

Wageningen Livestock Research is ISO 9001:2015 certified.

All our research commissions are in line with the Terms and Conditions of the Animal Sciences Group. These are filed with the District Court of Zwolle.

Public Wageningen Livestock Research Report 1353. 


\section{Table of contents}

$\begin{array}{ll}\text { Foreword } & 7\end{array}$

$\begin{array}{lc}\text { Executive Summary } & 8\end{array}$

1

$\begin{array}{lr}\text { Introduction } & 9\end{array}$

3

$\begin{array}{ll}\text { Approaching Colombian aquaculture } & 12\end{array}$

$\begin{array}{lll}3.1 & \text { Feed costs in Aquaculture } & 15\end{array}$

$\begin{array}{lll}4 & \text { Insect farming in the world } & 17\end{array}$

4.1 Key elements of successful insect farming around the world 18

$\begin{array}{ll}4.2 & \text { Insect farming in developing countries } \\ \end{array}$

$\begin{array}{ll}4.3 & \text { Insect farming in Colombia } \\ \end{array}$

$\begin{array}{ll}\text { 4.3.1 Small-scale } & 20\end{array}$

$\begin{array}{ll}\text { 4.3.2 Medium-scale } & 21\end{array}$

4.3.3 Potential large-scale initiatives 21

4.4 Stakeholders for an insect-based animal production value chain in
Colombia

4.5 Success and risk factors associated with the implementation of insect
farming in Colombia

$5 \quad$ Circular economy and peasant farming 25

$\begin{array}{lll}5.1 & \text { Economy: Managing our home } & 25\end{array}$

5.2 Transitioning to a circular economy 26

5.3 The transition from a linear and traditional aquaculture system to a
sustainable system based on a CE model

5.4 How does agroecology support the transition to a circular economy? 28

$\begin{array}{lll}5.5 & \text { Agroecological fish production } & 30\end{array}$

5.6 Circular economy policy of the Colombian National Government 33

5.7 Waste management and circular economy in Colombia 34

5.8 Approaching current circular agriculture practices among Colombian
peasants

6.1 Is there a pathway?

6.2 SWOT analysis for insect farming in aquaculture in Colombia 38

$\begin{array}{ll}6.2 .1 \text { Strengths } & 38\end{array}$

6.2.2 Weaknesses 38

6.2.3 Opportunities 38

6.2.4 Threats 38

6.3 Agroecological Insect-Fish Farming and its relation with the SDGs 39

6.4 Circular economy principles to develop agroecological insect fish farming 40

6.5 Income generation possibilities for Agroecological Insect-Fish Farming 42

$\begin{array}{lll}6.6 & \text { Production costs structure } & 44\end{array}$

$\begin{array}{ll}\text { Acknowledgements } & 48\end{array}$

$\begin{array}{lr}\text { References } & 49\end{array}$ 


\section{Abbreviations}

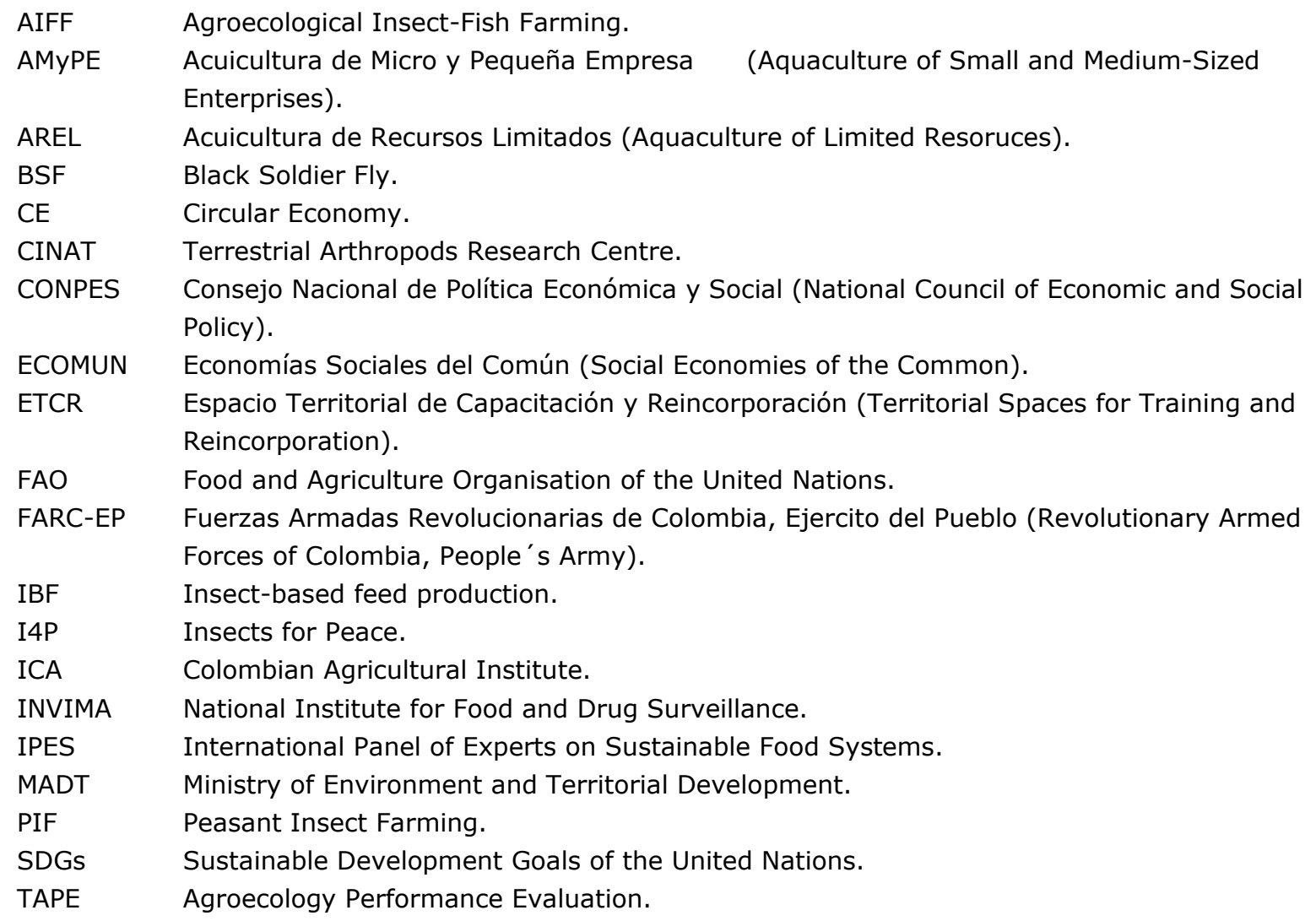

\section{Figures}

Aquaculture production in Colombia 2011-2020.

Fish farming in Colombia 2020.

Environmental, social and economic advantages that make insects an innovative alternative to address problems related to food production.

Stakeholders for an insect-based animal production value chain in Colombia. Just transition from an extractivist economy to a circular economy (adapted from Movement Generation, 2016).

FAO's 10 Elements of Agroecology. Source: FAO.

Combined production of rice and fish in a paddy field in Yogyakarta, Indonesia. Integrated agri-aquaculture systems in the Arhuacos indigenous community in the Sierra Nevada de Santa Marta, Colombia.

Periphyton fixed on wood substrate in integrated agri-aquaculture systems.

Diagram of the integrated agri-aquaculture system in the Arhuacos indigenous community.

Landscape of the integrated agri-aquaculture system in the Arhuacos indigenous community. Fishing activities of the indigenous community.

Local fish food production based on the Arhuacos indigenous community garden's resources.

Relationships between ecosystem services and farming intensity.

Analogical scheme representing the relationship between ecosystem services and fish farming intensity.

Agroecological Insect-Fish Farming in Colombia and its relation with the Sustainable Development Goals of the UN 2030 agenda.

General Description of the Agroecological Insect-Fish Farming model.

Circular economy principles applied to Agroecological Insect-Fish Farming in Colombia. 


\section{Tables}

1

2

3

4

5
Classification of fish farmers in Colombia.

Understanding the relationship between circular economy, agroecology and integrated aquaculture.

Lean Canvas Model* for AIFF exinsurgent members of the Icononzo project.

BSF production costs structure of the Icononzo project per fish cycle (4 months).

Fish production financial balance with and without BSF per 4 months. 



\section{Foreword}

The Dutch Minister of Agriculture aims to shift the focus of the Netherlands as exporter of goods to exporting knowledge and experience. The aim is also to contribute internationally to "building back better". Proteins from fish are very important to the health of especially poor people. Moreover, it is important to exploit organic residual streams to generate valuable products and income. Wageningen University \& Research has unique knowledge about the use of insects to convert organic residual streams into feed for livestock and fish. This report has been written in response to a request from the Ministry of Agriculture to investigate how insects as feed can contribute to circular agriculture while addressing not only SDG1 (no poverty) and SDG2 (zero hunger), but also SDG12 (responsible consumption and production), climate action (SDG13), life on land (SDG15) and peace, justice and strong institutions (SDG16).

This report has been written by a multidisciplinary group. Three out of the four authors were part of the agile circularity team at Wageningen University and Research (WUR) which developed new concepts for circular food system thinking.

Project members were Karol Barragán-Fonseca ${ }^{1}$; Adriana Muñoz-Ramírez ${ }^{2}$; Nils Mc Cune ${ }^{3}$; Julián Pineda4; Marcel Dicke5; Julián Cortés Urquijo6. Project leader was Teun Veldkamp

\footnotetext{
1 Assistant Professor Universidad Nacional de Colombia - Sede Bogotá - Animal Sciences Department - Centro de Producción de Artrópodos Terrestres. Bogotá, Colombia.

2 Associated Professor Universidad Nacional de Colombia - Sede Bogotá - Animal Sciences Department - UN- Acuictio. Bogotá, Colombia.

3 Associate Researcher, Agroecology and Livelihoods Collaborative, University of Vermont

4 Master student of Animal Sciences. Universidad Nacional de Colombia - Sede Bogotá - Animal Sciences Department - Centro de Producción de Artrópodos Terrestres. Bogotá, Colombia. Insect Farming Technologies - EntoPro

5 Professor of Entomology at the Laboratory of Entomology. Wageningen University \& Research. Wageningen, The Netherlands.

$6 \mathrm{PhD}$ candidate at the Sociology of Development and Change chair group at Wageningen University \& Research. Wageningen, The Netherlands.

7 Senior Researcher Animal Nutrition at the Animal Nutrition Division of Wageningen Livestock Research, Wageningen University \& Research. Wageningen, The Netherlands.
} 


\section{Executive Summary}

The circular economy (CE) has become relevant in various countries where governments and organizations have declared the intention to replace the traditional linear economy with policies addressed to develop circular models of economy; however, CE has traditionally already been practiced by some peasants and farmers in the world. This report presents the results of a research project to identify concrete conditions for the production of insects by small- and medium-scale farmers, enabling peasant communities to reuse organic residual streams to feed insects, and then, use these insects as feed in peasant-run aquaculture. We compare and conceptualize the synergies between the CE and agroecological approaches, proposing a theoretical model: Agroecological InsectFish Farming model (AIFF), as a new opportunity to develop a circular economy by implementing practices such as the use of insects, especially the Black Soldier Fly (BSF), producing high-value proteins for fish feed and consequently food for human consumption and a more sustainable planet. 


\section{Introduction}

Day by day, the circular economy (CE) has become more relevant in various countries where governments and organizations have declared the intention to replace the traditional linear economy with policies addressed to develop circular models of economy. In Colombia, CE policies are new. Only in 2019, the Colombian government launched a National Strategy of CE aimed at "transforming production and consumption chains through the efficient management of materials, water and energy" and at "motivating producers, providers, consumers and other actors from the productive systems to develop new models of business that include the management of waste, the efficient management of materials and the change of citizens' life styles" (Presidencia de la República de Colombia, 2019). This public policy opens an important door to develop CE experiences and research projects which, in the near future, can offer alternative ways of income generation for different sectors of Colombian society.

In the agricultural sector, however, CE has been practiced traditionally. Peasant farming used to involve several practices of circular agriculture, such as the reuse of manure to fertilize the soil and the use of crops to feed animals on the farm. More recently, other practices such as compost production, among others, are being included by peasant communities and families aiming at developing alternative sources of making a living and, in other cases, at developing small and local businesses. In the case of fish production, Colombian producers used to reuse fish bones in the form of fish meal or compost, viscera as fish oil or meal, water of the fishing ponds as fertilizer. Moreover, in small scale farms circular agriculture practices included, in a less technical way, the use of food waste and other residual products of the farm used as feed sources (such as poultry manure for water fertilization).

The use of insects as animal feed is relatively new in Colombia. Despite previous efforts developed by peasant farmers in an artisanal way, this activity is just beginning and already represents a promising productive sector and an alternative source of income generation for many peasants in the global south. Currently, it is not clear to what extent circular agriculture, based on insect production, can foster sustainable livelihoods in Colombian aquaculture economy. As such, this research project aimed to identify concrete conditions for the production of insects by small- and medium-scale farmers, enabling peasant communities to reuse organic residual streams to feed insects, and then, use these insects as feed in peasant-run aquaculture.

To develop this report, we carried out a literature review of the concepts: peasant economy, aquaculture, insect farming and CE using them to contextualize the current state of these components in Colombia. As part of the methodology, we made structured interviews to small-scale farmers, including indigenous fish farmers and ex-insurgents of the FARC-EP. Additionally, structured interviews with insect farmers were made to discover current insect production systems, insect species and practices among Colombian farmers. Data gathered were analysed to identify categories and common elements, in order to have a detailed picture of the current state of fish and peasant farming systems in Colombia.

This report is organized as follows: first, we describe the current context of Colombian peasant economy, followed by the current state of Colombian aquaculture. Then, based on insect farming experiences in other parts of the world and specifically in Colombia, we characterize the insect production system. After that, we conceptualize CE and its connection to traditional peasant farming, agroecology, and aquaculture. Furthermore, we propose a theoretical model for the transition to a peasant circular aquaculture to support peasant economy and small- and medium-scale farmers in Latin America. Finally, we present a prospective analysis of the economic impact of that transition. 


\section{Current state of the Colombian peasant economy}

The Colombian peasant economy has faced several problems in the last century. Machado (2017: 17) summarizes the historic transition of the agrarian conflict in Colombia as "the step from the control over the land by traditional big landowners and the peasant struggle for the land, towards the control over territories and the population by armed groups, criminal bands and capital".

Public policies aiming to reduce the problem of the lack of access to land included different strategies in the last century such as titling of owner-less lands, unsuccessful agrarian reforms, subsidized market of the land, debates about distribution of the land, the improvement of the use and exploitation of land, and more recently, the policy of restitution of land to deprived peasants in the conflict (Machado, 2017).

Another problem is related to the existing political violence that has dominated the countryside and so affected the peasant economy in different aspects. On the one hand, the violence promoted an illegal market of land with attractive prices for big landowners with strong relationships to the paramilitaries. This strategy included an aggressive and violent pressure on small peasants to force entire communities and families to sell their land at low prices (LeGrand, 2016; Sanín, 2015).

The Green Revolution generated a strong dependence of small farmers on external chemical inputs for agricultural production. This produced side effects such as the rise of food prices due to monopoly of the chemical supplies in a few companies and the reduction of agricultural diversification which implied both the reduction of varieties and the focus on intensive agriculture and monocrops. More recently, due to free trade agreements with different countries, some policies aiming to restrict the use of traditional seeds, to certify seeds and to promote the use of transgenic seeds have strongly impacted the traditional peasant farming and so the income of the peasantry (Solano, 2012; Mejia, 2019).

The control of the production and commercialization of food by a few multinational companies (Fajardo, 2014) has reduced the role of local and traditional markets, thus impacting the income generation of peasant families. The role of intermediaries in the commercialization of food, the lack of an appropriated infrastructure in the country side, and the high costs of agricultural inputs, among others, reduce the profitability of food production, leading to a move of peasants to other kinds of economies such as traditional mining (nowadays illegalized by the Colombian government) and the coca economy (including cropping coca which is also illegal in Colombia) (Sanín, 2021; Espinosa, 2004).

That is how, in the last decades, the need for sustainable livelihoods, especially in remote rural areas, has motivated the incursion of small- and medium-holder farmers in coca crops which, at the same time, has led to local violence and the mafia who produce, commercialize and control the drug trafficking business. This illegal market, much more profitable than producing food, has also replaced traditional peasant culture with a narco-culture in which values and ethics have been strongly impacted (Rojas-Sotelo, 2014; Naef, 2018).

Machado (2017) emphasizes that currently a process of urbanization of the countryside exists in which an outrageous speculation of land prices occurs due to an active market driven by money laundering but not by the conversion of land into productive assets. As a consequence, the attractiveness of the land is no longer due to the land itself as an economic asset but as territory. Thus, currently the political value and the possibility of the control of entire regions -including natural resources- are more relevant for those interested in land trade.

The Colombian peasantry, however, is not a homogeneous entity and so, peasant economy is not uniform. Different scenarios have been used, depending on geographic and strategic position, culture, ownership of the land, use of the land, and so on. While peasants in some regions are dedicated to produce coffee in their own small plots, in others, they are workers and day laborers (jornaleros) in big banana crops or coca harvesters (raspachines) in hidden crops in the middle of the jungle. While some peasants possess parcels of hundreds of hectares, in others, they have one or half of a hectare or are landless peasants just surviving selling their workforce. While some peasants bear extreme 
conditions of poverty, others organize themselves in peasant guerrillas or social organizations and others are assassinated and prosecuted by irregular armies and paramilitaries many of them supported by the Colombian state (Comisión Histórica del Conflicto y sus Víctimas, 2015).

The effect of the violence produced in the countryside in the last decades has also affected the peasant economy. Over 5.7 million displaced people (Grupo de memoria histórica, 2014) in the last 50 years, most of them from peasant origin, have been relocated to the cities where peasants, traditionally dedicated to traditional faming activities, are now working guarding buildings, cleaning houses or just surviving in the streets doing popular economy activities. In the 1960 s, $50 \%$ of the Colombian population lived in the countryside while nowadays, about $15 \%$ inhabit the countryside (World Bank, 2021), developing rural-related activities such as mining, transport, agriculture, livestock, fishing, and so on.

Peasant knowledge has also been affected by this migration. Much of the countryside is nowadays inhabited by elderly people and new generations of peasants do not find it attractive to live in the countryside and work the land. The lack of access to services provided in the cities, the lack of connectivity, the low income obtained from agricultural labour, among others, decrease the willingness to live in the countryside. This, together with the impacts of the Green Revolution, has produced the loss of traditional peasant knowledge which affects the way peasant economy is perceived and the future of the Colombian rurality.

Despite these historical issues that negatively affected peasant life in Colombia in the last decades, more than $80 \%$ of the food is still produced by peasant farmers (Minagricultura, 2016), and innovative scenarios of economy are being developed in the countryside considering the agriculture potential of the Colombian territory. One of these initiatives is the promotion of the agroecological mode of production by local actors, social leaders, peasant organizations and academics. Agroecology has been promoted as a sustainable alternative to produce healthy food and to provide sustainable livelihoods to farmers. As in other Latin American countries, Colombians are also worried by the effects of climate change and are looking for production alternatives that protect the environment and follow the principles of the circular solidarity economy, to become an option for future generations. 


\section{Approaching Colombian aquaculture}

Aquaculture is probably the economic food sector with the fastest growth in the world, and is responsible for $50 \%$ of the fish used as food in the world (FAO, 2020c). The Colombian Ministry of Agriculture and Rural Development (MADR) reported that aquaculture production is developed mainly in three states of the country (Figure 1), with an increase between 2011 and 2020, from 82,622 to 179,351 tons (MADR, 2021; Figure 2). From this total volume, fish production provided 174,067 tons, where the main species grown were $58 \%$ tilapia (Oreochromis spp), $19 \%$ cachama (Piaractus brachypomus and Colossoma macropomum), 16\% rainbow trout (Oncorhynchus mykiss) and $7 \%$ native species. On the other hand, 5,284 tons of white shrimp (Litopenaeus vannamei) were produced in the same period, steadily growing in the last five years in the Caribbean and the Pacific coast areas of Colombia. The aquaculture sector is developed nowadays within 36,268 farms that generate 53,805 direct jobs and 161,416 indirect jobs. However, despite the growth registered, aquaculture represented only $0.3 \%$ of the gross national product in 2020 and $3.3 \%$ of the agricultural gross product (MADR, 2021).

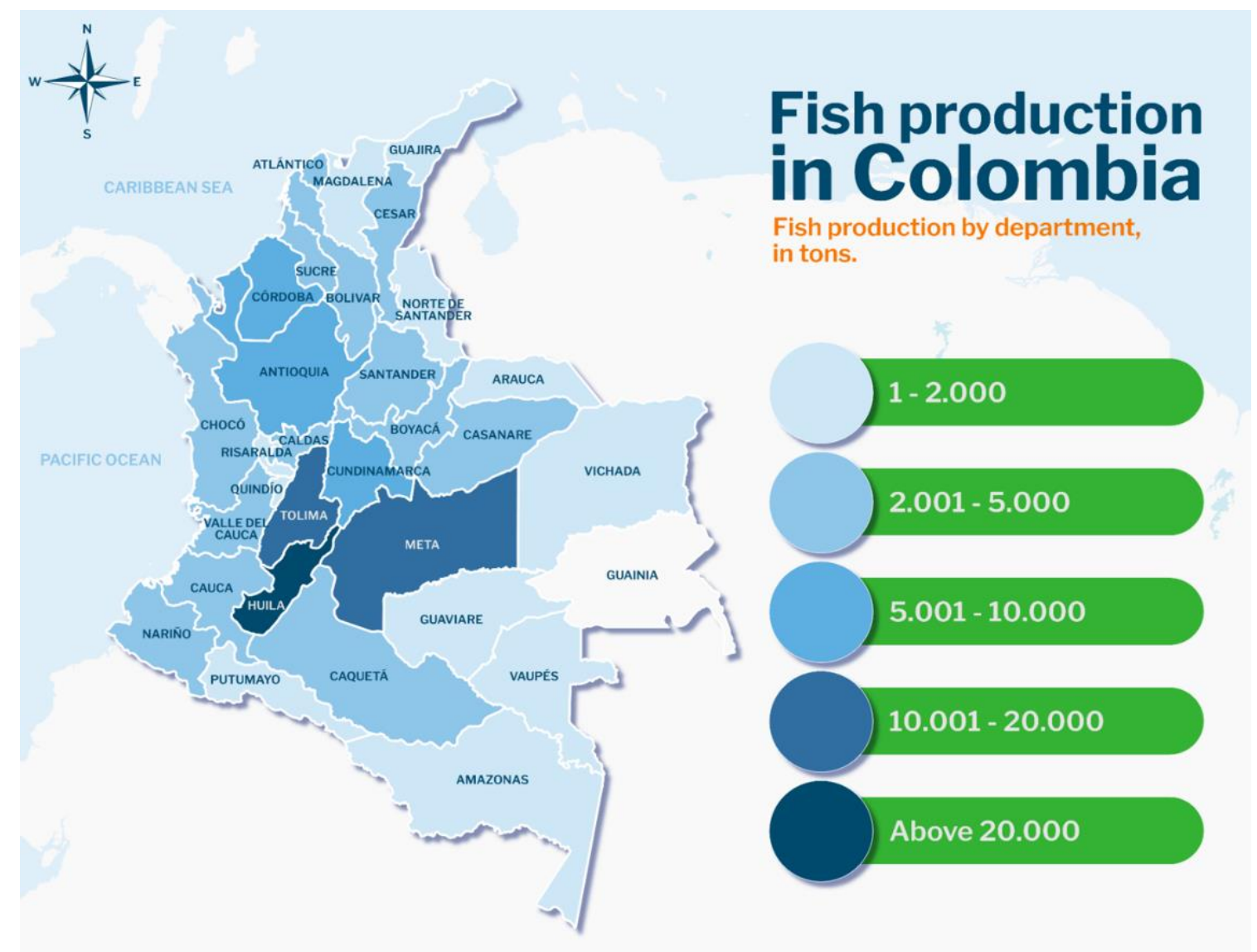

Figure 1 Aquaculture production in Colombia 2011-2020. Adapted from MADR (2021).

In Colombia, as stated in Resolution 1607 of 2019 by the National Aquaculture and Fishing Authority $\left(A \cup N A P^{7}\right)$, fish farmers are classified into four categories, based on their activity, their system of production and the volume of production (Table 1). 
Table 1 Classification of fish farmers in Colombia.

\begin{tabular}{lllll}
$\begin{array}{l}\text { Kind of fish } \\
\text { farmer }\end{array}$ & $\begin{array}{l}\text { Production } \\
\text { (tons/year) }\end{array}$ & $\begin{array}{l}\text { Area (Ha's of } \\
\text { Water mirror) }\end{array}$ & $\begin{array}{l}\text { Total assets (in } \\
\text { smlmv }{ }^{*} \text { ) }\end{array}$ & Features \\
\hline Subsistence & Less than 10 & Less than 0.65 & Less than $284 * *$ & Self-consumption and selling of surplus \\
\hline Small & 10.1 to 22 & 0.65 to 1.5 & Less than $284 * *$ & Self-consumption and selling of surplus \\
\hline Medium & 22.1 to 240 & 1.51 to 15 & 284 to 5000 & Market oriented \\
\hline Big & More than 240 & More than 15.1 & More than 5000 & Market oriented \\
\hline
\end{tabular}

* Monthly minimum salary in Colombia in 2021: 908526 COP (about 207 euros)

** Included assets of spouses or partners.

Source: Resolution 1607 from 2019. AUNAP.

Aquaculture in Colombia is delimited by the state and organized as a productive chain which includes seed producers (fingerlings and shrimp post-larvae), feed producers, breeding farms, processing companies, supply commercialization, exports, research centers, academia, and final product commercialization. This organization is also reflected in nine regions, which integrate the 32 departments of Colombia. Each region has a regional committee of the aquaculture value chain, that promotes the activity and collects local information about production, commercialization, achievements and needs of the sector. Some departments are notable for the production volumes: Córdoba (3\%), Antioquia (4\%), Cundinamarca y Boyacá (6\%), Tolima (9\%), Meta (11\%) and Huila (39\%); on the other hand, for shrimp production the two main departments are Bolivar (89\%) and Nariño (10\%) (MADR, 2021; Figure 2).

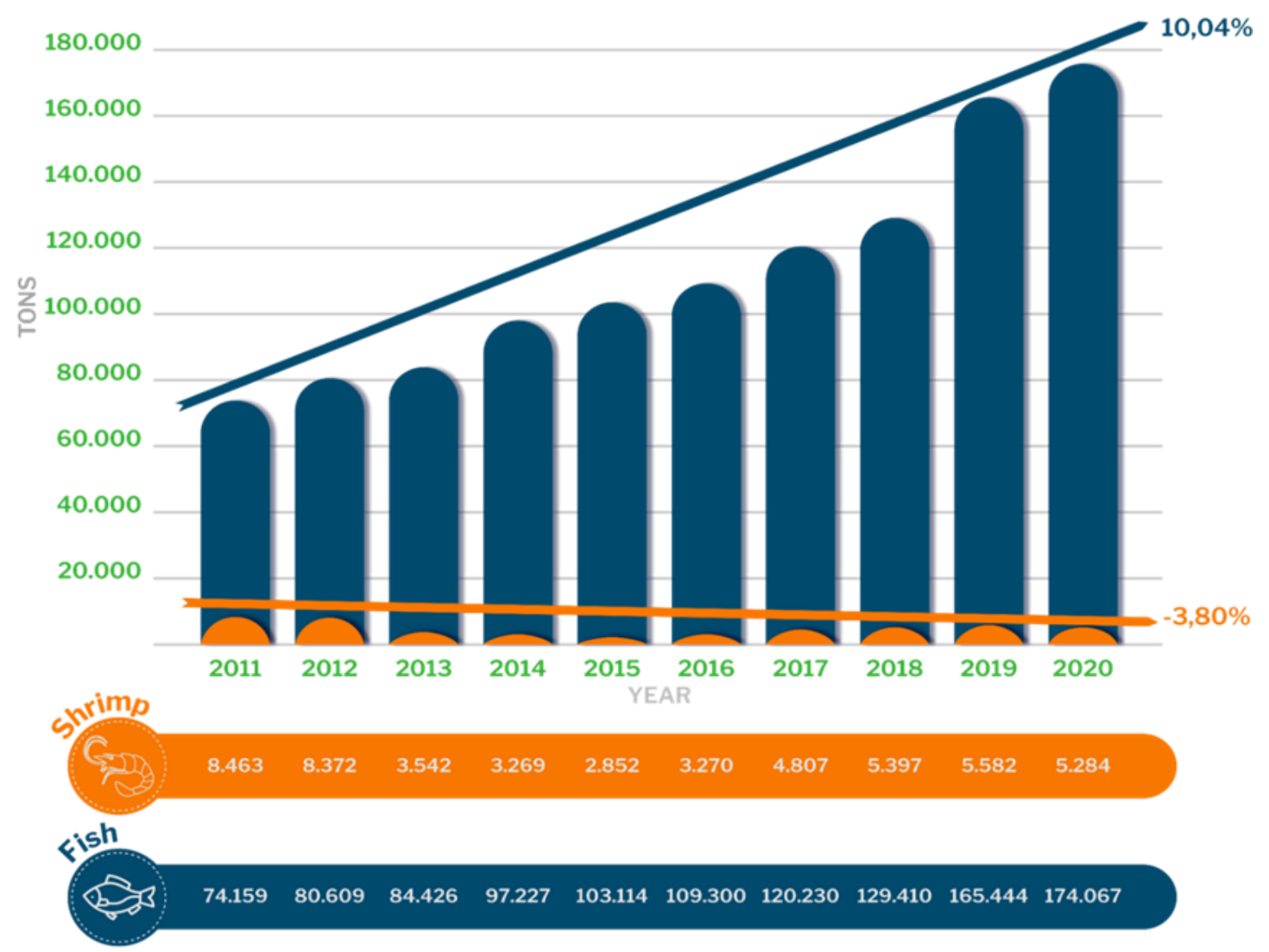

Figure 2 Fish farming in Colombia 2011-2020. Adapted from MADR (2021).

In recent years, there is a growing interest in improving quality standards, production practices and in obtaining national and international certificates, which has generated increased competition. In 2019, Colombia had 66 fish farms with certification of good practices of aquaculture production BPPA (Norma Técnica Colombiana NTC 5700:2014 ${ }^{8}$ ) and 39 fish farms with international quality standard BAP (Best

8 NTC 5700:2014 https://www.icontec.org/rules/buenas-practicas-de-produccion-de-la-acuicultura-bppa/ 
Aquaculture Practices) (MADR, 2020). Sixteen processing plants were certified by HACCP (Hazard Analysis and Critical Control Points), six of them being authorized to export to European Union (MADR, 2021).

As a result of this growth in competitiveness, in 2020,17,569 tons of tilapia, trout and shrimp were exported with a value of \$USD 92.4 million. MADR reports that during 2020, the volume of tilapia and rainbow trout exported grew by $47.91 \%$ compared to 2019 . The main destinations of the exports were the USA for the tilapia, the USA and Germany for trout and France and Spain for shrimp.

Despite the steady growth of aquaculture in Colombia, the per capita consumption of fish products in 2020 was $8.8 \mathrm{~kg} /$ person/year which is less than the consumption of pork, beef and chicken meat, with averages of $10.8,17.1$ and $36.4 \mathrm{~kg} /$ person/year, respectively. In that sense, the national consumption of fish products was less than the value reported by the Food and Agriculture Organization of the United Nations (FAO) for Latin America and the Caribbean (10.5 kg/person/year) and for the rest of the world (20.3 kg/person/year). This represents a potential for the fish production sector in Colombia, whose market is currently supported by imports, but that could be provided by local production with high quality standards and supported by consumer campaigns that provide information about origin, management, nutritional content and safety of national fish production.

With respect to the impact of the COVID-19 pandemic, FAO (2020a) highlighted that global fish production had decreased by $6.5 \%$ at the end of April of 2020 due to the restrictions and the lack of labour. Other factors that have impacted the trade of food have been the measures taken to avoid the spread of COVID-19 such as confinement, prohibition of traveling, closing of restaurants and other shops, among others (Dirección, 2020). Other indirect impacts were the reduction of demand of products with a consequent reduction of production activity and the difficulties related to logistics, transport and border restrictions. Other consequences of the pandemic are the reduction of the quality of life of the producers due to the low-income generation and the reduction of food and nutritional security across the world (FAO, 2020b). In response to the crisis, it is clear that there is a need to take measures and actions in biosecurity, communication, marketing, commercialization, technology, innovation and other factors that allow an adaptation of the sector (FAO, 2020a).

According to Muñoz-Ramírez et al. (2020), an optimistic scenario is open to opportunity for innovation, creation, and the use of existing virtual tools. Despite this crisis, it is expected that between 2018 and 2030 there will be a growth in the aquaculture production in Perú (54.4\%), México (47.7\%), Brazil $(32.2 \%)$, Chile (30.3\%) and Argentina (24.8\%). The business plan for the fish farming sector in Colombia (FEDEACUA, 2015), concludes that Colombian aquaculture also has the opportunity to grow, however, a great information gap for the activity in Colombia is the lack of a characterization of the different types of producers, particularly with regard to critical elements that make a difference in the business models that each type or class of fish farmer applies and what are the limitations to achieve the optimal performance of the respective business model. There are also differences between fish farmers, related to the level of formalization, the technology or production system used, the level of integration of different links in the value chain, aquaculture and product processing practices, the relationship with marketing channels and above all, the scale of production. These are key elements for characterization and are the basic reference to define the importance that associativism can have, as a way to overcome many of the limitations that can be found in these issues.

Despite the above and to achieve the expected aquaculture industry growth in Colombia, several challenges need to be faced: Improving the productivity and competitiveness, diversification of aquaculture with new species, modernization of the current production systems, promotion of fish products, legal formalization of fish farmers, strengthening of associations, development of production systems in natural and artificial waters, development of a research agenda in aquaculture, institutional articulation of the implementation of good aquaculture practices, environmental sustainability and social development, and improvement of current loan and financing services. Other Latin American countries also facing challenges such as environmental sustainability, improvement of productivity and competitiveness and social development (Muñoz-Ramírez et al., 2020).

In Latin America, as Flóres-Nava (2013) suggests, one can clearly distinguish an aquacultural sector dedicated to the intensive industrial production such as salmon and shrimp, and a second sector of Aquaculture of Limited Resources (AREL) or Micro and Small-Scale Aquaculture (AMyPE), mainly self- 
employed and with a low level of formal education, which presents a high vulnerability due to its limited resources to face any crisis. Crowley (2020) suggest that in countries such as Chile, the contribution of big fish companies is more pronounced than that of small-scale fish producers. However, the role of the Small-Scale Aquaculture $\left(\mathrm{APE}^{9}\right)$ in providing livelihoods for communities must be recognized. In the future, APE represents an alternative to providing a regular income for artisanal fishers or to supplement their income when facing the negative effects of climate change.

Aguilar-Manjarres and Flores-Nava (2020) argue that fishing and aquaculture in Latin America should become a local development strategy, being capable of using their own resources and becoming an important element of the food supply chain in crisis times. The FAO (2020b) also suggests that new policies should build a value chain capable of absorbing external impacts allowing the sustainability of the fishing sector through collaboration with other countries, with public sectors and private investments which, altogether, can enhance the development of policies, management and technical advice.

In the diagnosis of AREL and AMYPE in Latin America, based on information from 16 countries $^{10}$, Flóres-Nava (2013) suggests that the lack of access to nutritional and affordable feed and the lack of access to loans are limiting factors to the self-sustainability of these productive initiatives. From direct observations in Bolivia, Paraguay and Colombia, it is estimated that fish feed accounts for $85 \%$ of the direct cost of production in AREL. In that sense, Flóres-Nava emphasizes the need to support studies about the availability of alternative fish feed and the formulation of non-traditional diets. Flores-Nava and Estrada-Münzemayer (2011) mention that one of the most important needs to strengthen aquaculture sector and inland fishing is the nutritional evaluation of alternative sources of protein that are nationally available for use in aquaculture. Indigenous peoples in Latin America (more than 800) should have a protagonist role in the decision making process at regional, national and international level, not only to guarantee their self-determination rights, but also to consider their contribution in the reformulation of development models (such as Buen Vivir), in the way they relate to nature, and their knowledge and practices to care and conserve biodiversity, especially nowadays when climate change needs to be mitigated (CEPAL y FILAC, 2020).

\subsection{Feed costs in Aquaculture}

As reported by the FAO (FAO, 2020), the aquaculture market is growing and adding value to the cultures and countries that produce fish as a protein source for human consumption due to the population increase in the years to come, as predicted by the United Nations. Fish feed used by fish farmers and facilities is an important issue related to the effect on the feeding conversion ratio, fish growth and the cost incurred by the quality of balanced diets and the raw materials used to mix diets (Baki \& Yucel, 2017).

In terms of location, market, environmental and human resources, every single fish farmer is unique. These elements have an impact on the business and family success of big, medium and small-scale fish farmers around the world. As mentioned before, economic success in aquaculture systems depends directly on the feeding strategy because the feed used importantly affects production costs and, thus, farmers have moved to new and innovative systems trying to reach best profits and optimizing their income (Ahmed, 2007).

Most fish farmers agree that the feeding cost is the most important aspect to be dealt with to improve their production systems (El-Naggar, Nasr-Alla, \& Kareem, 2008). The profitability in aquaculture is commonly measured by cost-benefit analysis systems (Olasunkanmi, 2012). The price of the raw materials and ingredients needed for balanced diets for aquaculture is a key factor in the cost and economic analysis. Several aspects such as the price of oil, the reduction in cereal production, the el Niño effect, the regulation of producing fishmeal and the ocean's environmental destruction affect the price of fish feed around the world. For example, the price of fish meal increased from \$USD 500 to \$USD 1210 per ton between 2000 and 2008 (Rana, Siriwardena, \& Hasan, 2009).

Thus, there is a need to find new ways to produce local raw materials, and to produce them in a sustainable way, cost-effectively, based on CE and providing opportunities for innovation in the

9 APE (Small Scale Aquaculture) is an activity managed by families, with few employees or in charge of a small community, which can revert the crisis situation of current fisheries and over exploitation of fish production that face the world. (Crowley, 2020).

10 Argentina, Belice, Bolivia, Brasil, Colombia, Costa Rica, Chile, Ecuador, El Salvador, Guatemala, México, Nicaragua, Panamá, Paraguay, Perú y Uruguay 
aquaculture sector (Thorarinsdottir, Jokumsen, Bjornsson, \& Torrissen, 2011). Small fish farmers commonly optimize their production systems by reducing feed costs using natural resources, working with the family members to reduce the workforce costs and selling directly on the fish markets (Anokyewaa \& Asiedu, 2019; Barragán-Fonseca, Barragán-Fonseca, Verschoor, van Loon, \& Dicke, 2020).

A new protein source to feed fish in a sustainable way that can be locally produced is the BSF which can reduce the cost related to the fish feed (Henry, Gasco, Piccolo, \& Fountoulaki, 2015; Magalhães et al., 2017; Ferrer Llagostera, Kallas, Reig, \& Amores de Gea, 2019; Smetana, Schmitt, \& Mathys, 2019) not only by replacing the commercially balanced diets but also adding value and improving health, natural behavior and quality of the fish fed with BSF larvae (Foysal, Fotedar, Tay, \& Gupta, 2019; Devic, Leschen, Murray, \& Little, 2018; Sealey et al., 2011). 


\section{$4 \quad$ Insect farming in the world}

Since 2003, FAO suggests that one of the main ways to address food and feed security is through insect farming, because insects are everywhere, they reproduce quickly and have high growth rates and feed conversion. Moreover, their production has a lower environmental impact during their life cycle compared to the production of livestock. They are nutritious, as they contain high levels of protein, fat, and minerals. They can be raised by taking advantage of various waste streams, such as food waste and animal manure. The use of insects as feedstock for aquaculture and poultry feed is likely to become more prevalent over the next decade (Van Huis et al 2013).

The breeding of insects for human and animal food purposes has grown exponentially in the last decade (Sogari et al. 2019) Industry players are rapidly investing in R\&D and in marketing to capitalize on emerging trends in the food and beverage industry by introducing innovative highprotein, low-fat, yet affordable products along with changing trends. The size of the edible-insect market exceeded $\$ 112$ million globally in 2019 and it is estimated to grow at more than $47 \%$ CAGR (Compound annual growth) between 2019 and 2026, which would be an approximate projection value of 710 trillion dollars by 2026, according to a report by Global Market Insights Inc. (2020) ${ }^{11}$.

This growth is also reflected in the growing number of countries and companies that are taking an interest in this market. Among the countries that most generate this market are: USA, UK, the Netherlands, France, Belgium, Canada, China, Thailand, Vietnam, Brazil, Mexico, Kenya and South Africa. Currently, there are more than one hundred companies in the world that are producing different species of insects for this purpose and are investing in the modernization of this sector. These companies include: Agriprotein Technologies (South Africa), EnviroFlight (Spain), Thailand Unique (Thailand), Enterra (Canada), Bestico (the Netherlands), Protix (the Netherlands) and Ynsect (France).

The use of organic waste for feeding insects is already implemented by several companies in different countries. For example, AgriProtein in South Africa leads a new industry, called nutrient recycling, which uses organic waste to create proteins to meet the growing demand for animal feed. It is a global project focused on the production of fish and meat to serve the growing world population. By using BSF larvae fed by abundant waste nutrient sources, AgriProtein has developed and tested a new largescale, and potentially sustainable protein source. The bioconversion process takes low-cost waste materials and generates valuable goods. Various types of waste are used, including human waste (faeces), slaughterhouse blood, and food waste (AgriProtein, 2012).

The company Enviroflight is another producer of BSF for animal feed. Enviroflight's goal is to produce plant and animal protein for aquaculture feed. Enviroflight uses dried distillery grains and used beer grains to feed BSF. By doing so, the BSF yields a high-protein, low-fat food for tilapia, freshwater prawns, catfish, and other omnivorous species. The material is also valuable as a protein source for pigs and livestock. The larvae are used as a high-protein and high-fat ingredient for carnivorous fish such as rainbow trout, perch, sea bass, and bluefish. They are cooked, dried, and made into food containing $42 \%$ protein and $36 \%$ fat. Research projects such as Proteinsect, Entofood, or Bioflytech are dedicated to the reproduction of insects which, through bioconversion, process organic waste into protein for animal feed and into organic fertilizers for plant nutrition. It is important to highlight that all this processing of organic waste in Europe is regulated in the CE policies that the European Union has installed since 2015.

In summary, it is clear that insect farming is growing fast in the world and its benefits can be seen at the large, medium and small scale (Van Huis et al. 2020). First, big multinationals produce insects as feed on a large scale (tonnes of larval biomass/day). The overall growth of the insect-rearing sector is particularly related to the growth of the BSF-producing companies. BSF production has grown rapidly, from 7,000-8,000 tonnes wet weight in 2014-2015 to 14,000 tonnes in 2016 (Koeleman, 2016). Second, micro-enterprises satisfactorily produce insects offered at the local level due to the use of simple technologies, especially in the field of aquaculture. Third, small-scale farmers for whom BSF is

\footnotetext{
${ }^{11}$ Global market research and management consulting company.
} 
also highly suited, rear this species with important social benefits and income generation opportunities (Barragan-Fonseca et al. 2020a; Chia et al. 2019a). On the other hand, there are non-profit organizations like The International Platform of Insects for Food and Feed (IPIFF), which is a European non-profit organisation, that promotes the use of insects for human consumption and animal feed, and strengthens the science-policy interface.

\subsection{Key elements of successful insect farming around the world}

The world is facing the negative effects of the oldest and the most impacting industry: industrial food production. Agriculture already uses approximately $30 \%$ of the available land on Earth (United Nations, 2020). Up to $70 \%$ of this area is exploited for industrial production of common livestock (Ritchie et al., 2020). Agriculture itself is responsible for $70-85 \%$ of water footprint (Pfister and Bayer, 2014) and food production is responsible for more than 25 billion ton $\mathrm{CO}_{2}$-eq., representing more than $50 \%$ of overall GHG emissions from all the sources globally (49 billion ton $\mathrm{CO}_{2}$-eq.) (Smetana et al. 2016). Meat production, as valuable protein, is the most impacting sector in food production (Steinfeld et al. 2006). The ever-increasing world population raises essential questions about our future capacity to produce and provide access to adequate food. It is estimated that the world needs an increase of $70 \%$ in the global food production by 2050 (compared to 2009) to fulfil the additional need for food, feed and high quality protein (Payne et al. 2016).

On the other hand, the food supply chain produces more than 1.3 billion tons of food and agricultural waste, which poses serious environmental problems (Kojima and Ishikawa 2013, Ravi et al., 2019). This is coupled with a high production of manure that becomes a problem during the long-periodcomposting process (Bortolini et al. 2020). Environmental pollution, population increase, water availability and misuse of land are inexorably driving humans to take on important challenges related to sustainability (Cadinu et al. 2020). Additionally, high prices of ingredients for animal feed represent a serious concern (Van Huis et al. 2013), particularly in the aquaculture sector, where the total production of feed is predicted to increase by $75 \%$, from 49.7 million tons in 2015 to 87.1 million tons in 2025 (Hua et al. 2019).

Scholars say that interlinked solutions based on the usage of knowledge, introduction of innovative solutions and technologies, reduction and prevention of food waste, improvement of food system governance and sustainable food production is needed (Ites et al. 2020). Insects become an alternative protein source of human and animal nutrition (Smetana et al. 2016) since the bioconversion and nutritional upcycling of waste biomass by insects yields high-value products such as protein, lipids, chitin and frass, bioactive peptides, organic manure, and other micro, macro-nutrients (Ravi et al. 2019). Insects such as the BSF (Hermetia illucens), the yellow mealworm (Tenebrio molitor), and the housefly (Musca domestica) are promising species (Barragan-Fonseca et al. 2017, Sogari et al. 2019).

Insects are a valuable tool for the transition to a bio-based CE in the agri-food sector, which aims to "close the loop" of the lifecycles of products through greater recycling and reuse (Madau et al. 2020). Using insects in innovative business models would environmentally, socially, and economically improve the performance of agri-food systems (Borrello et al. 2016, Chia et al. 2019a). Moreover, in 2015, the United Nations adopted the 2030 Agenda for Sustainable Development aimed at joint action to achieve food security and improved nutrition, promote sustainable agriculture, and combat climate change. Numerous Sustainable Development Goals (SDGs) are relevant to the use of insects for food and feed and directly connected to the CE framework (Madau et al. 2020, Dicke 2018). In sum, insects have numerous environmental, social and economic advantages that would make them successful alternatives to replace the traditional linear production model with a CE model (Figure 3). 


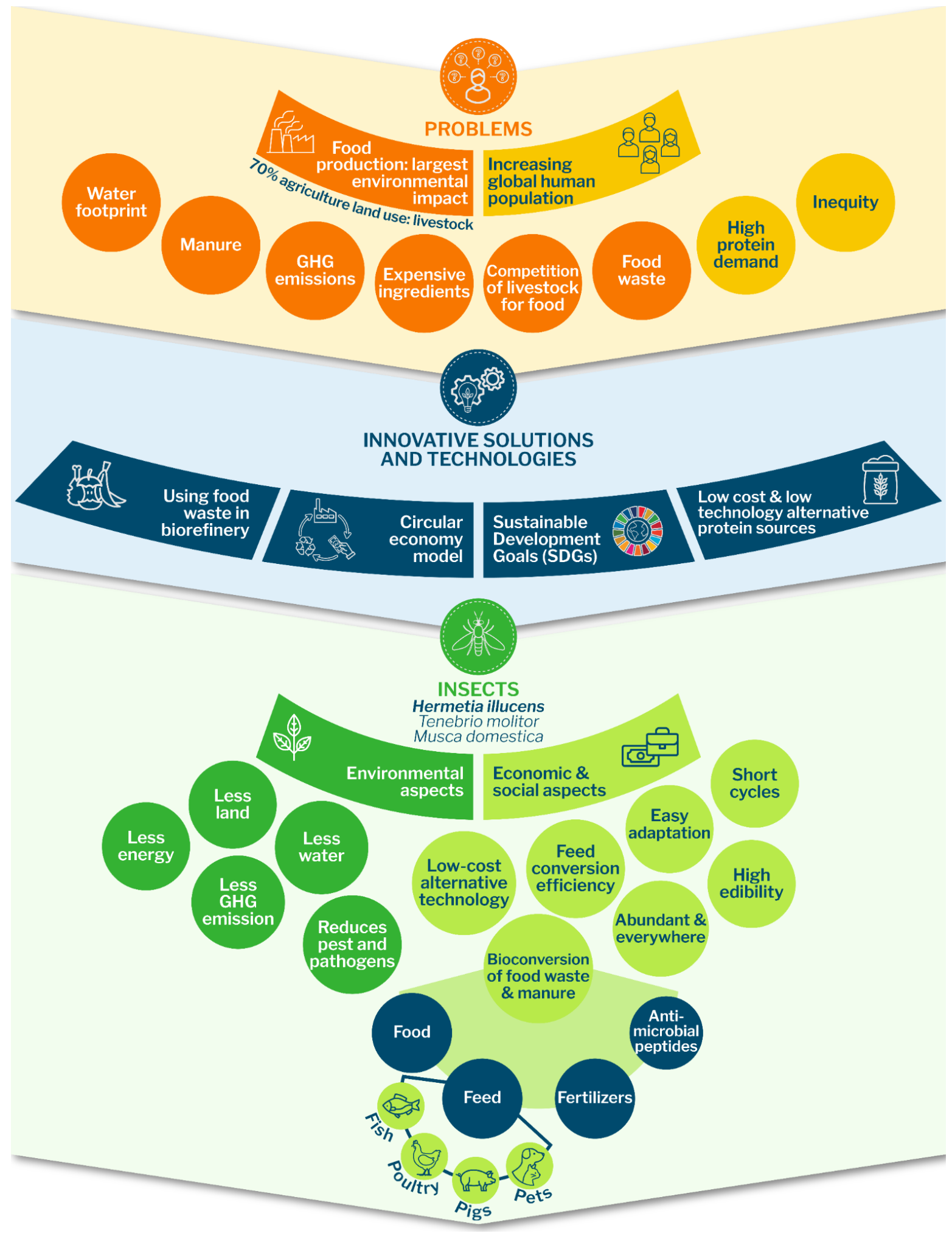

Figure 3 Environmental, social and economic advantages that make insects an innovative alternative to address problems related to food production. 


\subsection{Insect farming in developing countries}

As mentioned before, insect feed supply can be characterized at three scales: large, medium and small. For this purpose, exploring insect farming for aquaculture to fight rural poverty based on CE, we focus on small-scale insect farming, or what we have named Peasant Insect Farming (PIF). While peasant farmers are responsible for the basis of global food production, low income communities do not necessarily benefit by gaining access to commercial value chains (Poole, 2017). Integrating peasant farmers in a $\mathrm{CE}$, thereby making them stakeholders in the agribusiness value chain can help improving their quality of life in a sustainable way (Chia et al., 2019a). For peasant farmers, the most important costs in livestock production are represented by the costs of feed which amount up to $70 \%$ of the total costs, especially due to the costs of protein components. This makes farmers economically dependent on imported feeds that are commonly based on fishmeal and soybean meal. In Kenya, for instance, BSF larvae are produced locally by peasant farmers providing opportunities to become feed suppliers instead of being feed buyers. Kenyan peasants rear BSF larvae as feed component either to be included in feeds that they formulate themselves or to sell it to feed millers. Then insect meals compete with feeds based on fishmeal considering its protein source and its good performance as animal feed (in poultry, fish and pigs) (Chia et al., 2019b).

Additionally, since the left-overs of insect production can be used as biofertilizer, farmers who adopt insect production may also become independent of expensive, externally derived crop fertilizers (Beesigamukama et al., 2021, Barragán-Fonseca et al., 2020a). The environmental conditions of most developing countries are good for producing insects. The relatively high energy consumption required for insect production is mainly needed to maintain optimal temperatures for larval production in temperate countries. Thus, exploiting environments that match optimal temperatures (such as tropical regions) reduce energy use (Chia et al. 2019a). However, the economic performance of insect-based feed production (IBF) in tropical countries could be largely determined by labour costs and the procurement of rearing substrates as was observed in the geographical context of West Africa. Thus, IBF production systems in close proximity to substrate providing operations and nearby markets appear recommendable (Roffeis et al. 2018). On the other hand, insects like BSF may also be used in environmental sanitation programs to improve human health conditions. For instance, in Africa, private companies currently convert human waste from slums into organic fertilizer and fly larvae. These initiatives help sanitize the environment of poor communities (Chia et al. 2019a, Dicke 2018).

\subsection{Insect farming in Colombia}

In Colombia, the insect industry is not yet as much developed as in Europe or North America. However, we have identified experiences related to the different insect production scales (micro and small) and potential initiatives, most of them linked to academic initiatives from the Universidad Nacional de Colombia (UNAL). According to Dicke (2019), small scale farmers would produce between $10 \mathrm{~kg}-50 \mathrm{~kg} /$ week fresh larvae, while the medium scale farmers would range between 0.4 tons fresh BSF larvae per week to 3 tons per day.

\subsubsection{Small-scale}

In 2019, UNAL initiated the project "Use of the BSF as an alternative feed to reduce costs and improve the quality of life of ex-combatants in the process of reinstatement of the Icononzo-Tolima region" within the frame of a major project called Insects for Peace (I4P). Just as in Kenya, this project contributes to a circular agriculture allowing the production of sustainable feed components without significant technology. When BSF provides a good return on investment, culturing this fly may become a solution in Colombia's war against illicit drug production (Barragán-Fonseca et al., 2020a). Integrating insect farming may promote rural development contributing to the well-being, sustainability, as well as organizational, institutional and commercial strengthening of peasant farmers.

BSF production as an innovative and low-cost alternative to expensive imported feed can also become an alternative driver of reincorporating ex-insurgents in Colombia by providing BSF products to local economy. Thus, BSF can become an important contributor to peace in Colombia, as it provides a 
realistic and profitable option for peasant farmers, guaranteeing their livelihoods and contributing to food security and a CE (Barragan-Fonseca et al., 2020b).

Ex-insurgents in Icononzo are currently enthusiastic and have engaged in rearing BSF as an economic option. They aim to replicate the experience in other regions where they have settled. Nowadays, this BSF production plant replaces $15 \%$ of the traditional fish feed of their tilapia production. Besides, this plant is also used as a training place for other ex-insurgents. This initiative has three main outcomes: building community links, academy-community interaction and a BSF plant production (BarragánFonseca et al., 2020b).

I4P started as an initiative to use insects as feed and food to support peace and CE in Colombia and an inspiration from the experiences of the Kenyan productive peasant developments in farming insect for animal feed (Dicke, 2019). However, it can be promoted to other conflict-torn societies. I4P has also drawn the attention to the Dutch company Weendle which produces BSF as feed. This company foresees the opportunity to use the rearing of BSF in a refugee camp as a means to improve the living conditions of refugees and to provide intensive skill training not only in BSF Larvae (BSFL) rearing but also in project management through the initiative I4P. Although insect rearing may have intrinsic social benefits, those impacts are often portrayed as corollary of the main economic purpose. Yet, I4P approaches insect rearing essentially as a means to foster social transformation, particularly in areas where populations suffered from war.

We also identified an additional 22 small companies or productive initiatives which are working on insects as feed and food in Colombia. Through structured interviews, we established that $58 \%$ of these initiatives are set up in Bogotá, Cundinamarca and Antioquia. Most of them (44\%) work with BSF, and the rest with different species (mealworms, crickets, cockroaches, etc.) with the main objective being to produce animal feed. Their main concerns about insect production are related to regulation and a lack of insect production-related knowledge. All of them ask for installing an association of insect farmers in order to address these concerns. $80 \%$ of them are small-scale and $20 \%$ are medium-scale.

\subsubsection{Medium-scale}

In Colombia there are some initiatives, in an initial stage, of insect production as feed and food. One such is EntoPro - Insect Farming Technologies, a spin-off company from the Universidad Nacional de Colombia dedicated to the potential use of the BSF for the management of organic waste and the production of raw material rich in nutrients for food formulation. This spin-off company is run by professionals, professors, and researchers from UNAL interested in developing the potential of insects, who also seek to apply the potential of insects in different areas through the development of research and protocols for the production of terrestrial arthropods. The other companies are working with BSF and crickets and their main objective is to produce meal for making animal feed (BSF) and food ingredients (crickets).

\subsubsection{Potential large-scale initiatives}

Currently, there is not a large-scale multinational producing insects as feed and food in Colombia. However, some companies from Europe are trying to get a connection in order to build this kind of business in this region. In Latin America, this field is still new but different people from Chile, Uruguay, Peru, Ecuador and México have established contacts with EntoPro and the Terrestrial Arthropods Research Centre (CINAT) at UNAL to initiate collaboration. On the other hand, Wageningen University \& Research (The Netherlands) and UNAL brought together a group consisting of small and large private industry (Colombian and Dutch), academia and the Dutch embassy in Bogotá, which identified opportunities, challenges as well as legislation and knowledge needs in order to develop insects for feed in Colombia, with a focus on BSF. A great interest was identified in developing BSF production for feed in Colombia by insect farmers, poultry farmers, feed producers and academia. Dutch private industry and academia are willing to help in developing this transition (Dicke et al. 2020). 


\subsection{Stakeholders for an insect-based animal production value chain in Colombia}

Stakeholders of the insect-based animal production value chain in Colombia include those directly involved in different parts of the value chain, such as BSF producers, feed producers, farmers (small peasants and medium-scale fish farmers, poultry and pig producers), and stakeholders at the beginning of the value chain, such as private and public organisations that produce organic waste and need to discard it at the lowest cost. In this study, we focus on peasant farmers (Figure 4).

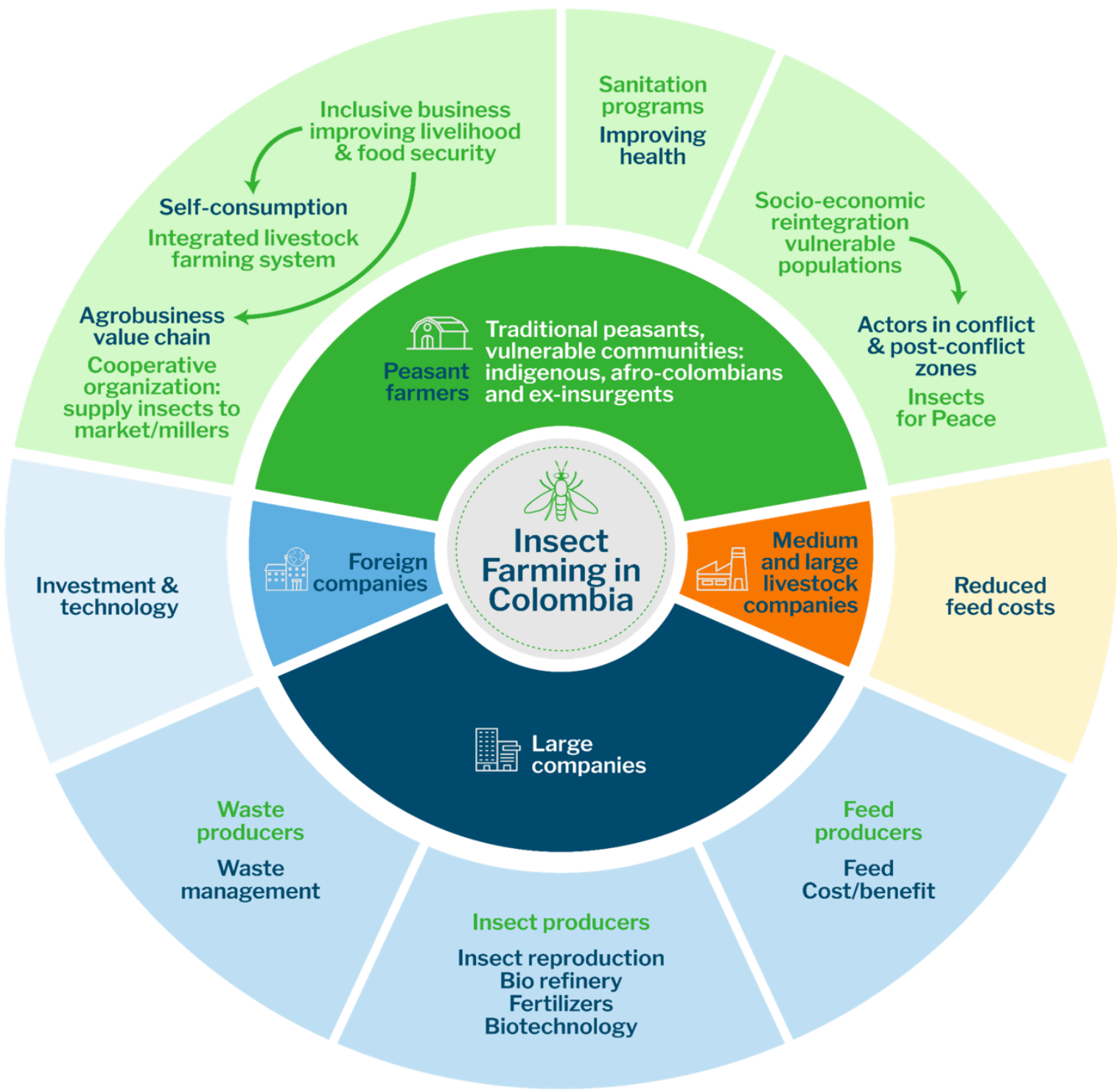

Figure 4 Stakeholders for developing an insect-based animal production value chain in Colombia. Elaborated by authors.

Currently, the Terrestrial Arthropods Research Centre (CINAT) and EntoPro, a spin-off of the National University of Colombia, lead research projects addressing various species of insects with the purpose of degradation of organic and inorganic residues for animal and human feeding purposes. For instance, Hermetia illucens, Gryllodes sigillatus, Tenebrio molitor and Zophobas morio. CINAT is leading processes to regulate insect use in Colombia with different institutions. Among these institutions are the Ministry of Environment and Territorial Development (MADT), the Colombian Agricultural Institute (ICA), the National Institute for Food and Drug Surveillance (INVIMA) and the Ministry of Agriculture. In this way, regulation in this area focuses on two basic fronts: the establishment of production systems for these insect species, their processing and commercialization. 
Although information on e.g. the biology, production, and nutrition of insects that are currently used as food and feed has grown exponentially, there are gaps that need to be filled related to the species, the objective of production and the final product that is intended to be commercialized. In general, the basic and applied research currently being developed by UNAL and its strategic alliance with entities such as Agrosavia, ICA, or MADT to lead this type of research, will strengthen interdisciplinary and transdisciplinary approaches to the establishment of regulation which can promote the development of innovative areas for the country's agricultural sector and aligned with global challenges and the Sustainable Development Goals (SDGs) proposed by the United Nations. For example, reducing poverty (SDG 1) and hunger (SDG 2), improving economic growth and employment opportunities (SDG 8), increasing employment and local technology development in low-income communities (SDG 9), improving gender equality (SDG 5), promoting sustainable use and reduction of food waste (SDG 12) and reducing effects on biodiversity due to overfishing and conversion of forests to agricultural land (SDGs 14 and 15).

\subsection{Success and risk factors associated with the implementation of insect farming in Colombia}

The experience to date with the incorporation of insect farming by the ex-insurgents' community can provide guidelines for its dissemination to peasant and medium-scale farmers. Similar elements exist between Kenyan and Colombian farmers that support the development of insect farming in Colombia. Icononzo's project, Insects for Peace and the Seed Money Project (Dicke et al. 2020) have allowed the identification of these shared elements: 1 . The need to develop legislation (which in the Colombian case has to be profoundly studied considering the economic context of the country), 2. Scientific research in academia, 3. The development of an enabling training environment by installing schools of trainers of trainers or by using the "peasant to peasant" methodology, 4. Improving business development at different scales, and 5. Developing (micro) financing.

Indeed, there are specific national conditions that can be addressed in a similar way as done in Kenya, such as the identification of the available suitable substrates, climate conditions, and infrastructure needed for optimal BSF production and the development of an insect-fed aquaculture value chain. However, specific Colombian circumstances such as its economic situation, attitude of farmers and the attitude of the general public towards insects as food and feed, and the armed conflict differ from Kenya, and need to be addressed in a different way. The armed conflict in Colombia has generated specific dynamics and types of rural communities. It is clear, that ex-insurgent rural communities and other peasant organizations are organized and have collective processes that could facilitate the incorporation of new technologies and agricultural production processes such as those of BSF farming. As ex-insurgents and peasant organizations are prone to make decisions and incorporation of new technologies in a collective way, the incorporation of insects as feed can be coordinated from the organizations' leaders and through workshops within those communities. Peasant and ex-insurgent associations and cooperatives will be decisive in this process (Barragán-Fonseca, et al., 2020a). Several conditions are likely to influence insect farming among communities in reincorporation: economic, material, organizational and learning conditions. Other elements include education and training, organization, productive projects, human rights challenges, farmer acceptance, and feed miller involvement. To be able to supply BSF meal to feed millers, a stable supply of sufficient volume with a stable insect quality is needed. Regulation in this field should focus on two basic fronts: the production of these species and their transformation and commercialization. This lack of clarity is greatly affecting the promotion and establishment of these promising alternatives, which are growing at a dizzying rate in other countries. At the legislative level, it is expected to implement insect production systems as another economic line in the area of national livestock production and to ensure that insect-based feed is safe and can be legally marketed by standardizing their use. There is a long way to go, at the regulatory level, that can support the development that is beginning in Colombia favouring these alternatives of animal production and animal protein that have proven to be sustainable from an economic, environmental and social point of view (Chia et al. 2019).

Considering the importance of empowering women among Colombian rural communities and the protagonistic role they have nowadays, an insect farming project should start with those organizational forms which guarantee the participation of rural women (Barragán-Fonseca et al., 
2020b). We acknowledge that the sustainability of an insect farming system in Colombia should be based on a solidarity economy by strengthening current organizational forms. Current

communitarian efforts to implement agroecological or integral farms and to return to local markets, can be strengthened by introducing insect farming by generating extra income and fortified circular agriculture practices. A BSF farming project also would need to create spaces of dialogue and involvement of communities from the beginning (Barragán-Fonseca et al., 2020b). To support the production and commercialization of insects in Colombia, several challenges should be addressed, mainly related to limited technology, lack of knowledge and the lack of regulatory clarity. 


\section{$5 \quad$ Circular economy and peasant farming}

This section addresses what exactly makes an economy circular, what should change, and how a CE relates to the experiences of peasant farmers in Colombia. Then we will compare and conceptualize the synergies between the CE and agroecology approaches, in order to identify a shared vocabulary and understanding. Next, we will explore the relationship between resource circularity and income in agroecological transitions, as a fundamental indicator of economic autonomy and endogenous development in peasant agriculture. Then, we will explore the relationships between $\mathrm{CE}$, agroecology and integrated Aquaculture-Agriculture systems followed by an exploration of agroecological fish production in Colombia. Subsequently, we explore the national policies of CE and the current availability of organic waste in Colombia to finalize by adressing existing circular agriculture practices among Colombian peasants.

Historically, traditional peasant farming has been a sanctuary of practices that today are understood as part of a CE. Seed saving, use of manure as fertilizer, crop-animal-tree interactions, slash-and-burn rotational cropping, polycultures, locally adapted animal breeds, and many other aspects of peasant farming coincide perfectly with the vision of circular agriculture. On the other hand, there is a rich theoretical tradition of studying the economics of peasant farming, or peasant economy (Chayanov, 1986). Peasant communities build economies of autonomy and resilience through their deep knowledge and reciprocal connection with nature (Toledo, 1990), their social institutions of sharing and local distribution through the "moral economy" (Scott, 1977) and their production of the factors of future production cycles (van der Ploeg, 2008). Peasant farming is not static, backward, or eternal; in fact, it is a permanently evolving, knowledge-intensive form of agriculture, based upon constant innovation and the search for economic solutions-through both engagement with, and mechanisms of distancing from, market forces and state institutions.

In this sense, the use of organic waste as rearing substrate for insects that in turn provide the feed for an aquaculture system, has the potential to become a key part of peasant strategies for building economically thriving, socially just, and ecologically sustainable rural communities.

\subsection{Economy: Managing our home}

What is an economy? As Box 1 shows, the word economy literally means "management of home". The Greek term oikos is the starting point for both ecology and economy. So why are these two disciplines so often seen as reflecting different interests, ideals and values? It is useful to think about the common root, and shared values, of both disciplines. While economics often only addresses instrumental values (i.e. the benefits that nature provides people), ecology tends to emphasize intrinsic values (nature, independent of people). Between these two extremes lie relational values, associated with the relationships among people or between people and nature (Caswell et al. 2021). Relational values are at the heart of the transitions analysed in both CE and agroecology literature. 
Box 1: The Meaning of Home. Source: Movement Generation, 2016.

ECO MEANS HOME: 'eco' comes from the greek word oikos, meaning 'home'

ECO SYSTEM ("home" + "TOGETHER")

Ecosystem means all relationships in a home-from microorganisms, plants, animals and people to water, soil and air. An ecosystem includes the terrain and the climate. An ecosystem is not simply a catalogue of all the things that exist in a place; it more importantly references the complex of relationships. An ecosystem can be as small as a drop of rain or as large as the whole planet. It all depends on where you draw the boundaries of home.

ECO logy ("home" + "KNOWLEDGE")

Ecology means knowing, reading and understanding home-and by definition, the relationships of home.

ECO nomy ("home" + "management ")

Economy means management of home. How we organize our relationships in a place, ideally, to take care of the place and each other. But "management of home" can be good or bad, depending on how you do it and to what ends. The purpose of our economy could be turning land, life and labor into property for a few, or returning land, life and labor into a balanced web of stable relationships.

Economy does not mean money, or exchange or financial markets, or trading or Gross Domestic Product. These are simply elements or tools of specific economies.

Economies ("how we manage our home") can be assessed in many ways: How healthy are the soil, people, water, animals? How much wealth is generated? Who owns the wealth? What even constitutes wealth? Is it money? Well-being? Happiness?

All economies have pillars in the natural, physical world, the view of our world that guides human actions, governance structures, and objectives (Movement Generation, 2016). At the core of any economy is people's work, according to the labor theory of value (Locke, 2015). Figure 5 provides a basic idea of how economies work according to people's belief systems, institutions and relationships with the natural world.

A series of historical factors have created a global economy based upon flawed systems and grave imbalances. The global economy was largely created through colonial ransacking and transatlantic slave trade, the plantation system, and militarism. Today, this system continues through fossil fuelpowered commodity flows, migrant labor, and militarism (see Figure 5). In material terms, this form of economy is largely linear-materials are extracted from nature, burned or consumed, and then dumped. Thus, two environmental problems are created within and through existing social inequalities: source problems and sink problems, which take on characteristics of neocolonialism, racism and patriarchy by disproportionately distributing waste products into the bodies of people of color and society, but particularly women, to assume the cost of the negative externalities (such as chronic illness, water scarcity and unpaid caretaking) that are not part of market transactions (Sanin, 2015; Fajardo, 2004).

\subsection{Transitioning to a circular economy}

How is a CE different from the linear, industrial, unjust economy described above? Jurgilevich et al. (2016) write that a circular food system "implies reducing the amount of waste generated in the food system, re-use of food, utilization of by-products and food waste, nutrient recycling, and changes in diet toward more diverse and more efficient food patterns." In this sense, the shift to a CE in the food system has many similarities with the concept of an agroecological transition, as well as the "just transition" concept that has been mobilized by the movement for climate justice (Raworth, 2017; Rockström et al., 2019). Figure 5, which visualizes an environmentally and socially just economic model, serves as a template for understanding the dimensions of closed-loop food systems, food 
sovereignty, and agroecology as a substitute for the agri-extractive food system model. As such, nutrient cycling is more than a technical problem; it is political as well, because it must contend with vested interests and worldviews that refuse to consider alternatives to the dominant model.

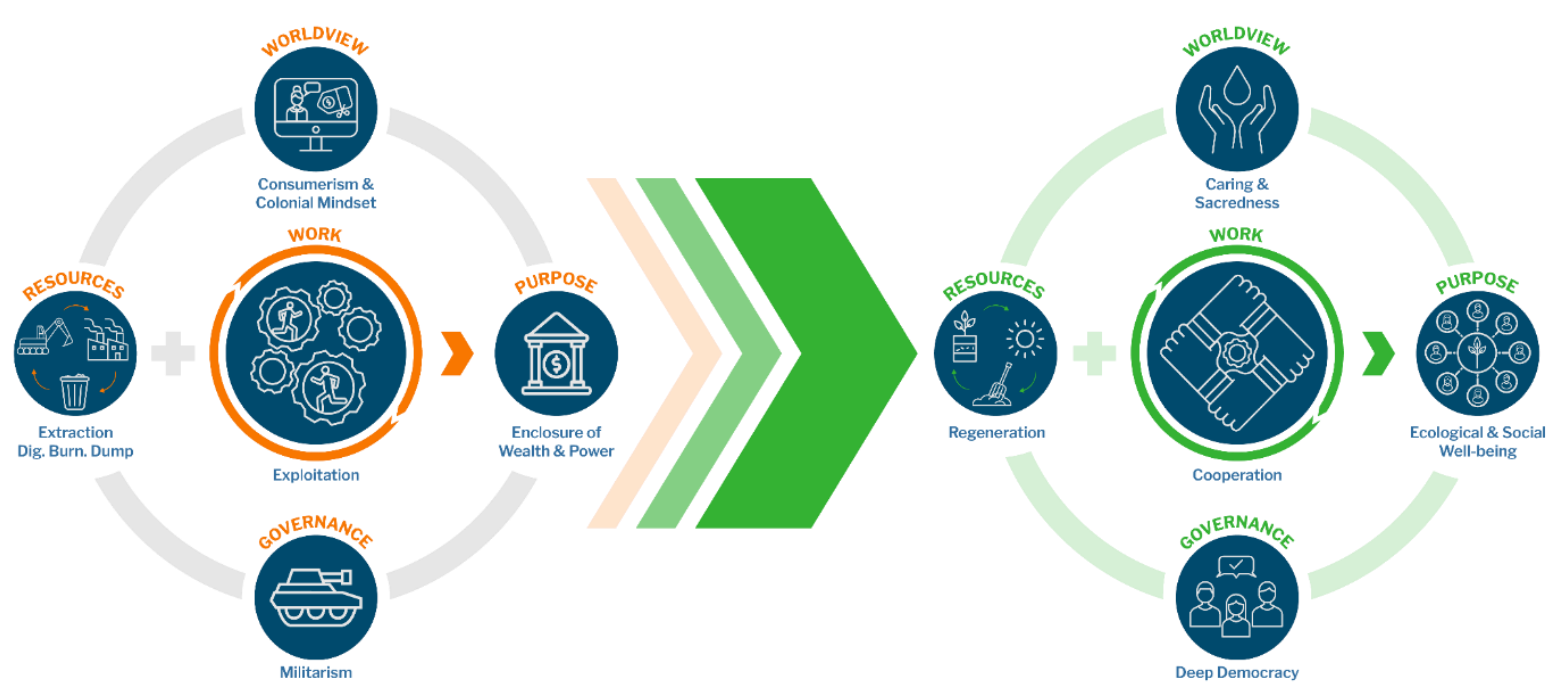

Figure 5 Just transition from an extractivist economy to a circular economy. Adapted from Movement Generation, 2016.

\subsection{The transition from a linear and traditional aquaculture system to a sustainable system based on a CE model}

Traditional aquaculture systems are also based on a linear economy. This economic model includes three steps:

- Take raw materials, natural resources and other ingredients from different suppliers to establish the process much easier and to focus on the product (in this case, fish). This refers, for example, to the water, tools and materials to cover and maintain the lakes or the ponds where the fish is being produced, and especially the commercial feed with high protein contents such as the fishmeal, the production lof which has a negative environmental impact.

- Make the product. This step involves the whole production process, from the new fish fingerlings to the commercial size to be sold. This is the core of the model, and the goals are to focus on optimizing resources and growing fish in an efficient way (less time and good quality and high quantity).

- Dispose of the leftovers, the waste and the surplus of the process. In linear systems the waste must be disposed someway as compost to a landfill, or contaminating the surrounding environment (water, air, land, plants and animals).

This linear model is the base of the industrial development where accessible materials and energy resources should be used in large volumes and at the lowest possible cost. Nowadays, goals (such as the SDGs) address different economic models that can restore the limited natural resources which have been ostensibly reduced in the last decades.

CE models seek to keep the highest utility of materials, components and products through a mix of technical and biological processes and giving the economy and business the opportunity to develop in terms of being sustainable, opening new jobs and reducing their carbon footprint.

There are different reasons for changing the traditional linear economic models to a CE. Economic losses and structural waste (due the large volume of waste generated), the price risk (every single component of the system is more expensive every day), the supply risk (we are using limited and non-renewable sources), natural system degradation (climate change, ocean pollution, land 
degradation and greenhouse gases), regulatory trends (new policies to be adopted by the population and the industries about carbon emissions and recycling), advances in technology (renewable energies), acceptance of alternative business models (the industries and new consumption tendencies are looking for different points of views and process) and urbanization (the growing population) are some of the reasons why a CE model is a new option for fish farming in this case.

\subsection{How does agroecology support the transition to a circular economy?}

Agroecology is the science that considers the ecology of food systems (Francis et al. 2003). Agroecology has emerged since the $1980 \mathrm{~s}$ as a response to the devastating impacts of agricultural modernization-a sort of counter proposal to industrial agriculture (Gliessman, 2013). It encompasses a science that understands farms as ecosystems, a set of productive practices that incorporate ecological principles into farming, and a global social process of people becoming engaged with farming and food systems (Wezel et al. 2009). Agroecology as a science combines peasant and indigenous knowledge with agronomy and systems ecology, in a scaled, systemic approach that recognizes biological, social, cultural and economic factors of complexity. As a set of productive principles, agroecology emphasizes nutrient cycling, energy and water efficiency, enhanced above-and below-ground biological diversity, and a fundamental reliance on locally available resources and knowledge, such as that found in indigenous polycultures the world over (Gliessman 1998), thus, connecting agroecology with many of the SDGs such as affordable and clean energy (SDG7), sustainable cities and communities (SDG11). The United Nations (UN) Special Rapporteur on the Right to Food recognized in 2010 that agroecological farming could double food production in many parts of the world, and with lower usage of water and energy resources (De Schutter 2012). Proponents argue that agroecological farming has the potential to slow, stop and even reverse global climate change (Grain 2011).

One of the guiding principles of agroecology is that the more the interactions between agroecosystem components resemble those that occur in natural ecosystems, the more likely the agroecosystem is to be sustainable over time (Jackson, 2002). In natural ecosystems, components such as plants (primary producers), herbivores (primary consumers), predators (secondary consumers) and decomposers such as soil fungi, engage in highly complex, reciprocal interactions. The complexity of these interactions helps to ensure that energy (which enters the ecosystem as sunlight), nutrients (which generally enter by tree root uptake) and water (entering as precipitation) are recycled within an ecosystem. This is called ecological efficiency. Agroecological design refers to the creation of agroecosystems with complex, circular flows of energy, nutrients and water, in order to maximize total system productivity (food products + ecological services) using a minimum of external inputs like fertilizer or irrigation water. By following nature's lead, agroecologists look to produce a sustainable yield that can be ecologically maintained over time and prove resilient even in challenging conditions, such as droughts, hurricanes or economic crises (Jackson, 2002).

The FAO has created frameworks for conceptualizing and tools for measuring the agroecological transition at different scales, including FAO elements (Figure 6) and, more recently, the Tool for Agroecology Performance Evaluation (TAPE) (FAO, 2019). Gliessman's classic transition framework is reflected in the approach taken by the International Panel of Experts on Sustainable Food Systems (IPES) (IPES-Food, 2018) and the High-Level Panel of Experts Report (HLPE, 2019). The world's academies contribute to its understanding, from political agroecology approaches (Anderson et al., 2019; Calle Collado et al., 2013), and metabolism of peasant social reproduction (Petersen et al., 2020). NGOs have also begun creating their tools for measuring agroecological transitions (Biovision, 2019; CIDSE, 2018). Over time, these assessment tools have shifted from a purely biophysical emphasis to include more indicators related to the politics, social actors and community selfmanagement.

As principal element of agroecology, the recycling of nutrients, biomass and water through biological processes within production systems increases resource-use efficiency and minimizes waste and pollution (FAO, 2019). 


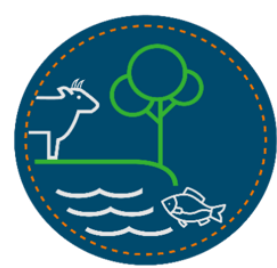

Diversity

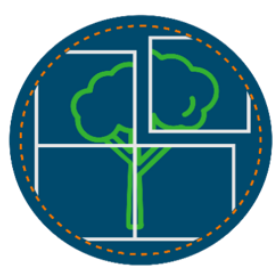

Co-creation and sharing knowledge

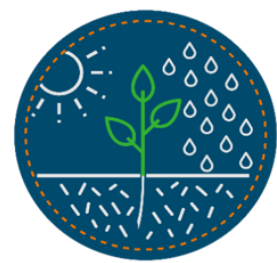

Resilience

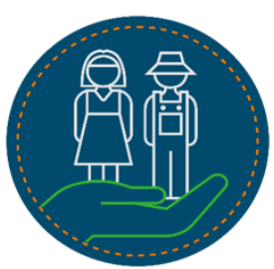

Human and social values

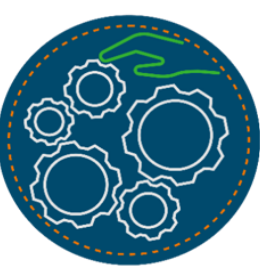

Synergies

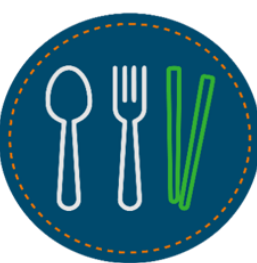

Culture and food traditions

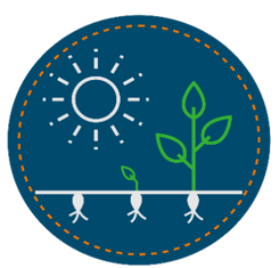

Efficiency

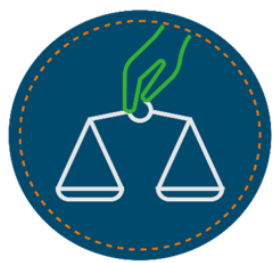

Responsible governance

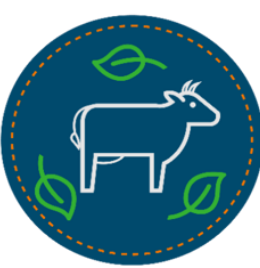

Recycling

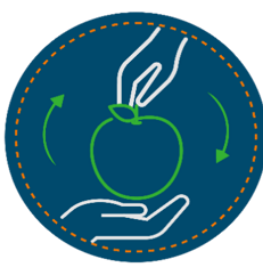

Circular and solidarity economy

Figure 6 FAO's 10 Elements of Agroecology. Adapted from FAO (2019).

In Table 2, the key features of the CE, agroecology and integrated aquaculture are shown, to clarify the complementary nature of both approaches. Agroecology emphasizes local knowledge and resources in building sustainable food systems, clearly connecting to the emphasis of recycling, reduction and reuse of resources in circular economies. Long-distance commodity flows require enormous quantities of fuel, transport and storage equipment, and inevitably contribute to food waste. Agroecology's orientation toward localizing and democratizing food systems can lead to more efficient use of water, and fossil fuels, by reducing the need for costly irrigation and agrochemical use in monoculture systems and using less long-distance transportation of food.

Table 2 Understanding the relationship between circular economy, agroecology and Integrated Aquaculture.

\begin{tabular}{|c|c|c|c|}
\hline Features & Circular economy & Agroecology & $\begin{array}{l}\text { Integrated Aquaculture- } \\
\text { Agriculture Systems }\end{array}$ \\
\hline What is it? & $\begin{array}{l}\text { The concept of sustainable } \\
\text { development with the most } \\
\text { traction in } 2021\end{array}$ & $\begin{array}{l}\text { The science, practice and } \\
\text { movement of sustainable } \\
\text { agriculture }\end{array}$ & $\begin{array}{l}\text { The most efficient way to use water } \\
\text { in order to produce food (e.g.: fish } \\
\text { and crops) }\end{array}$ \\
\hline Key phrase & Recycle, reduce, reuse & $\begin{array}{l}\text { Local knowledge, local } \\
\text { resources, local food systems }\end{array}$ & $\begin{array}{l}\text { Recycling nutrients, water } \\
\text { recirculation, aquatic species, } \\
\text { vegetables }\end{array}$ \\
\hline Macrosystem & Global economic structure & Global food system & Global blue-green system \\
\hline Microsystem & $\begin{array}{l}\text { Product, producer or } \\
\text { consumer }\end{array}$ & Agroecosystem & Water nutrient reuse \\
\hline $\begin{array}{l}\text { Theory of } \\
\text { change }\end{array}$ & Transition & Transition or transformation & To maximize the use of nutrients \\
\hline Priority areas & $\begin{array}{l}\text { Sourcing of materials, } \\
\text { material flows }\end{array}$ & $\begin{array}{l}\text { Sources of materials and } \\
\text { knowledge, nutrient flows }\end{array}$ & $\begin{array}{l}\text { Sources of materials and knowledge, } \\
\text { water and nutrient flows }\end{array}$ \\
\hline $\begin{array}{l}\text { Ecological } \\
\text { basis }\end{array}$ & Industrial ecology & $\begin{array}{l}\text { Systems ecology, } \\
\text { ethnoecology }\end{array}$ & Water ecology and agroecology \\
\hline
\end{tabular}

Own elaboration 


\subsection{Agroecological fish production}

Agroecological fish production is an age-old socio-technological system, particularly in Asia. Often combined with paddy rice, integrated agri-aquaculture is a productive system with high levels of ecological efficiency (Durán and Múñoz, 2016). Agri-aquaculture production systems may include ducks as well as fish and rice, with increasingly complex ecological feedbacks to prevent pests, diseases and weeds (Figure 7). These systems feature several elements of the CE.
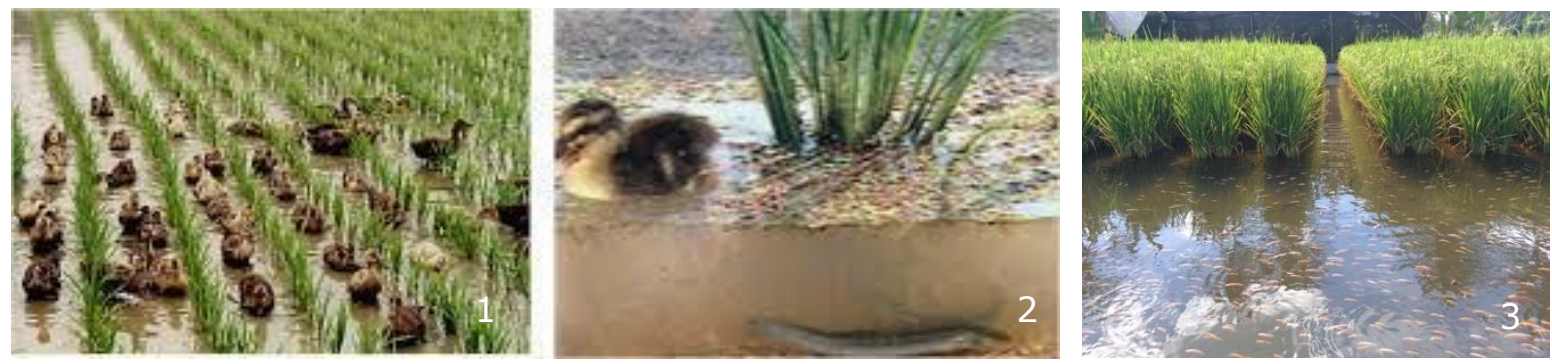

Figure 7 (1) Combined production of rice and fish in a paddy field in Yogyakarta, Indonesia. Photo: https://commons.wikimedia.org/wiki/File:Mina_padi_java_Pj_IMG-20150313WA0004.jpg.

(2) Rice-duck-loach-azolla production system in Japan.

(3) The operations simultaneously raise Aigamo ducklings, loaches (a fish species), rice and Azolla. The ducklings provide integrated pest management, replacing pesticides and herbicides by naturally controlling predaceous pest populations and digging up or eating competing weeds. Source: https://foolishfamilyfarm.wordpress.com/2017/02/18/riceduck-azolla-fish-cultivation-an-example-of-sustainable-farming/.

In Colombia, since 2016 the Arhuacos indigenous community living in the Sierra Nevada de Santa Marta, have implemented several systems of integrated agri-aquaculture by using feed produced on their own farm and by incorporating Periphyton as alternative feed (Durán-Izquierdo, 2019). Periphyton is a community of microbiota, algae, bacteria, fungus, animals, organic and inorganic debris adhered to an organic or inorganic (alive or dead) substrate (Figures 8 and 9) (Moreno, 2013), which is incorporated into the water to improve the water quality and increase the productivity. Periphyton is fundamental for the biotic structure of the water, where it is key for energy, mass and nutrient transfer through the trophic chains (Moreno, 2013; Thompson, Abreu and Wasielesky, 2002). These systems have been proposed as alternative to reduce the use of commercial feed in the production of hybrid Cachama (\&Piaractus brachypomus x of Colossoma macropomum) and Bocachico (Prochilodus magdalenae

The use of fixing surfaces of Periphyton in aquaculture, specifically in integrated agri-aquaculture systems allows a highly efficient and clean environment since it provides natural feed to the fish and improves the quality of the water (García et al. 2011; Voltolina et al. 2013). Recently, DuránIzquierdo (2019) analyzed the cost-benefit rate of agri-aquaculture systems with and without Periphyton implemented within the Arhuacos community showing that the most significant costs are related to the substrate, the supplementary diet produced with the resources of the farm and the fingerlings. The productivity was higher in systems with Periphyton ( $2133 \mathrm{~kg}$ fish/ha) than without it (1889 kg fish/ha). Likewise, income generation was higher under these conditions, similar to that reported by Uddin et al. (2009) demonstrating that the system is appropriate for the community 

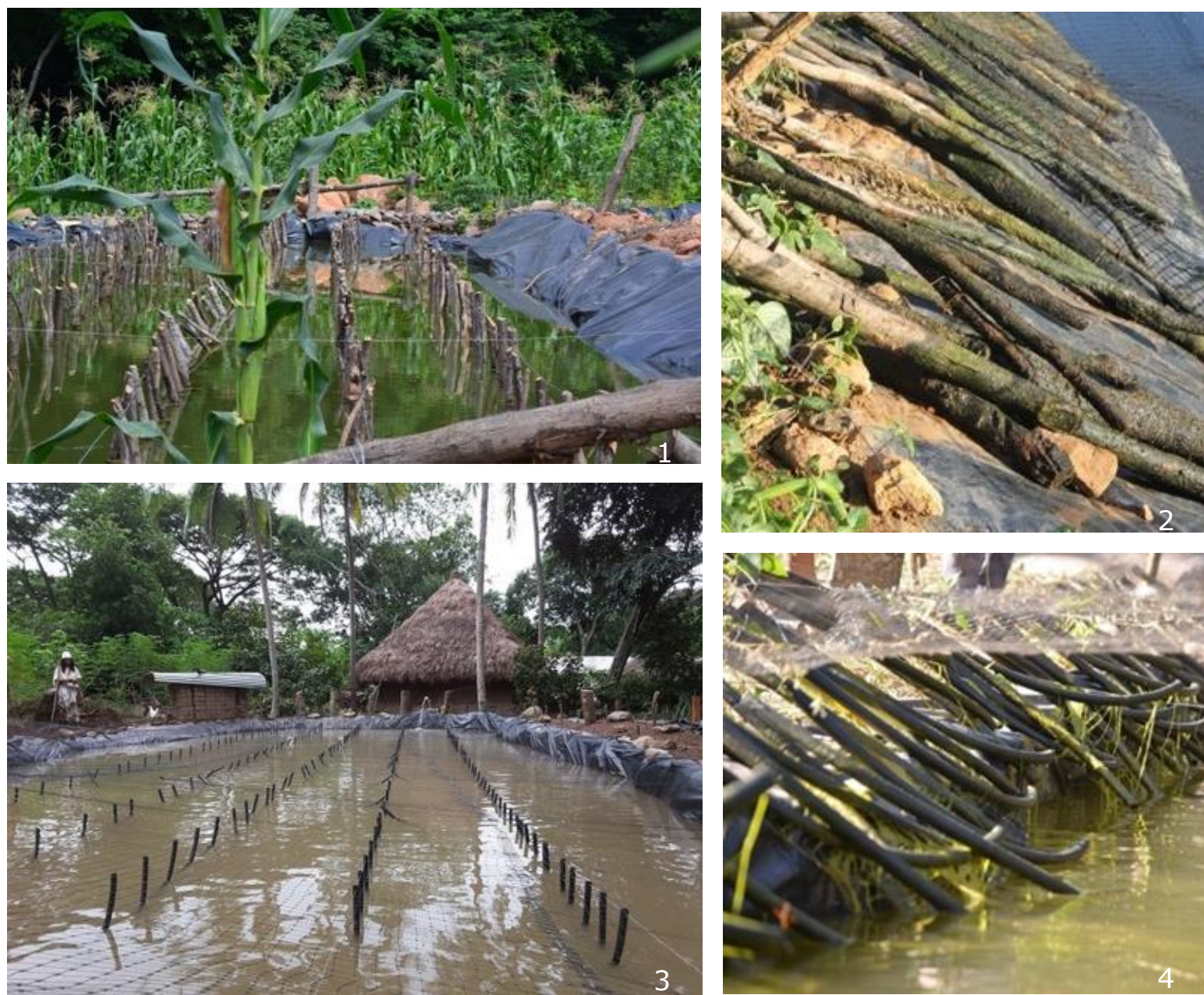

Figure 8 Integrated agri-aquaculture systems in the Arhuacos indigenous community in the Sierra Nevada de Santa Marta, Colombia. 1 and 2: Natural substrate in Wood. 3: artificial substrate in polyethylene 4: fixation of Periphyton. Photography courtesy of UNACUICTIO.
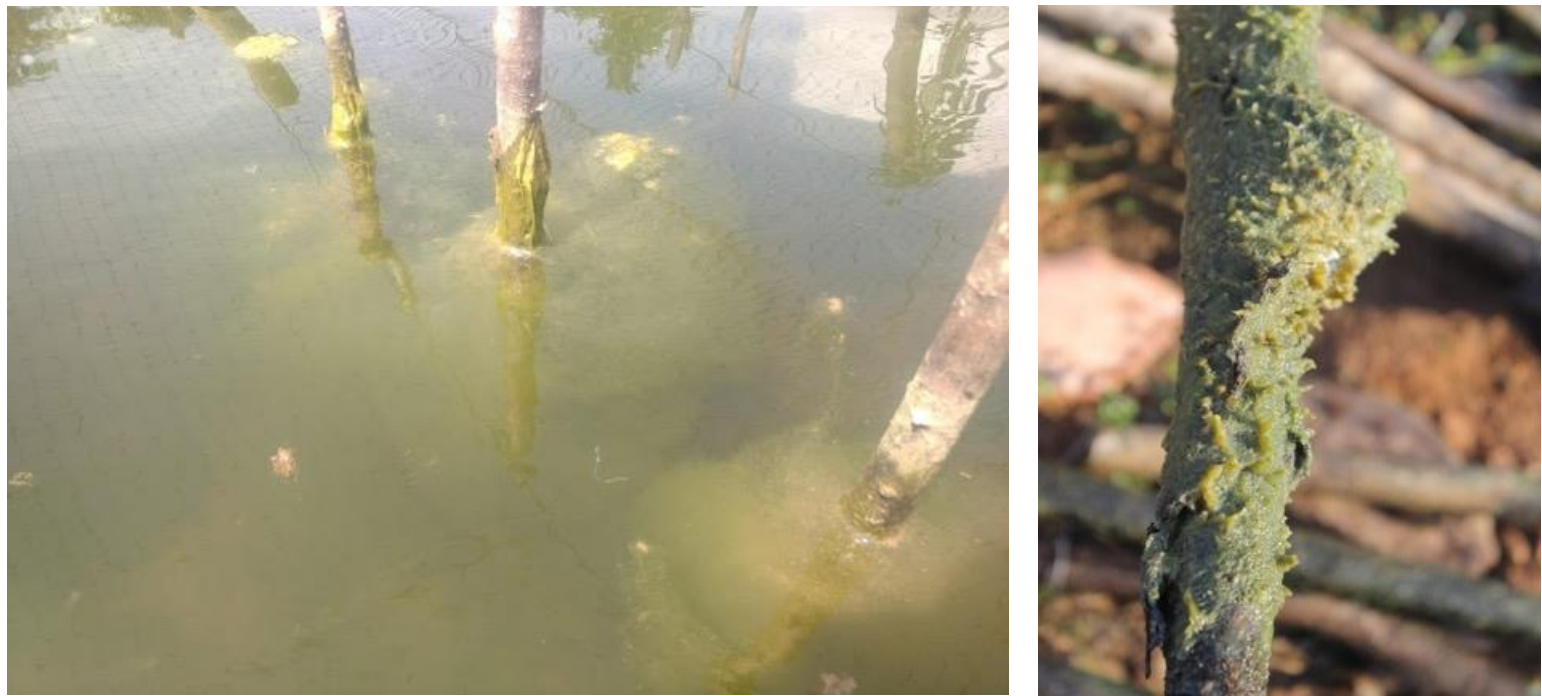

Figure 91 and 2: Periphyton fixed on wood substrate fixed in integrated agri-aquaculture systems Photography courtesy of UN-ACUICTIO.

Colombian experiences show that the implementation of integrated agri-aquaculture systems allows the community to develop local adaptations and to visualize nutrient flows and generate synergies (Figure 10). In this way, resources that were formerly rejected, are nowadays used in the system. The 
garden (Figure 11) not only produces vegetables, but also raw materials for the supplementary fish diet (Figure 12). Fish ponds produced also sediments and the water for the irrigation system which were used as organic fertilizer for the crops. The garden was the sub-system that merged productive with organizational activities of the family. Fish ponds represented the dynamizing space of the system which, at being innovative, strengthened collaborative labour, the use of local resources and the autonomy of the community.

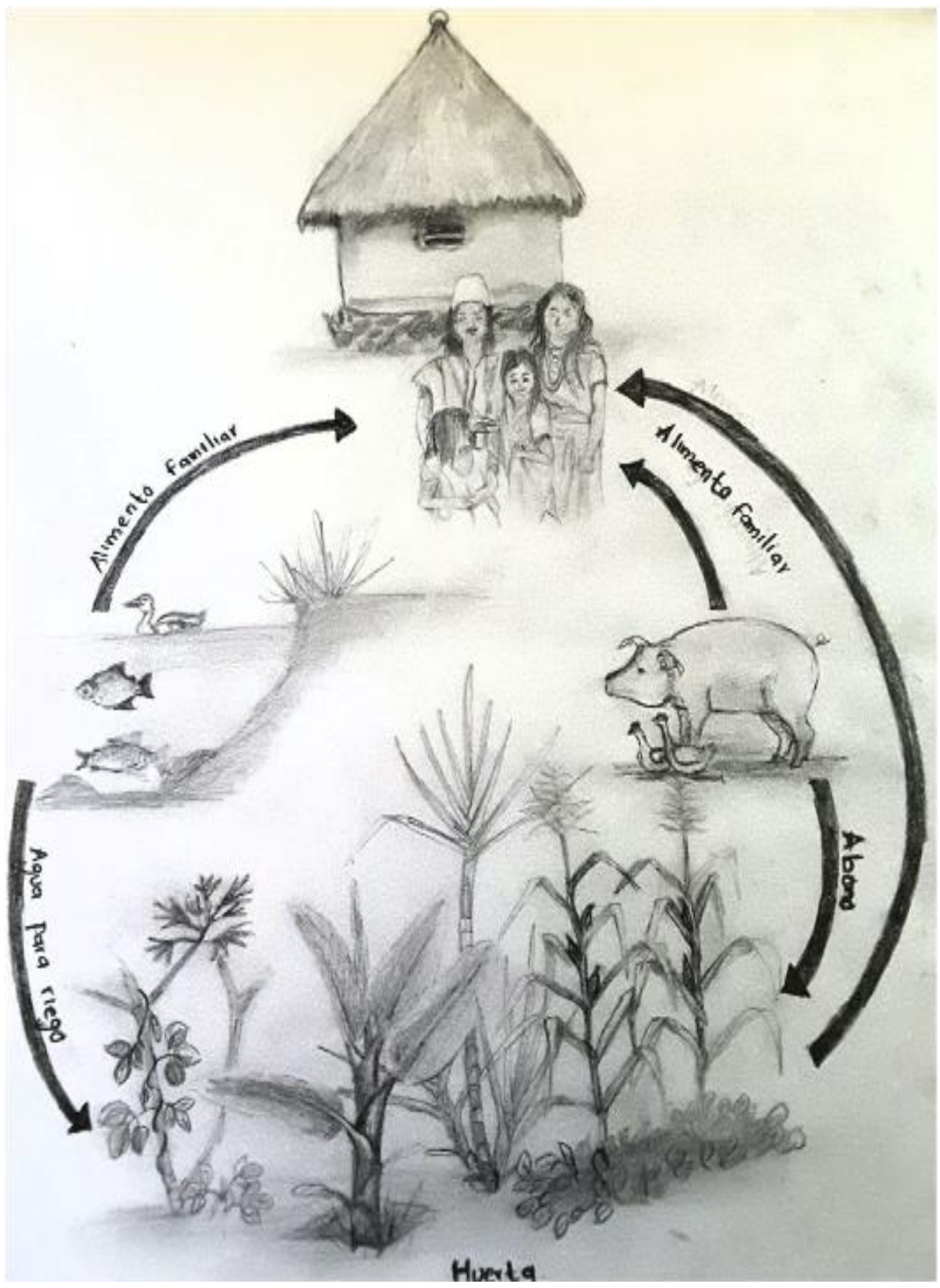

Figure 10 Drawing made by the Arhuacos indigenous community of their integrated agriaquaculture system in. It shows the resoruces flows (water, food, manure, feed) and synergies generated. Source: Dwawin Durán, member of the Arhuacos indigenous community, 2017. 


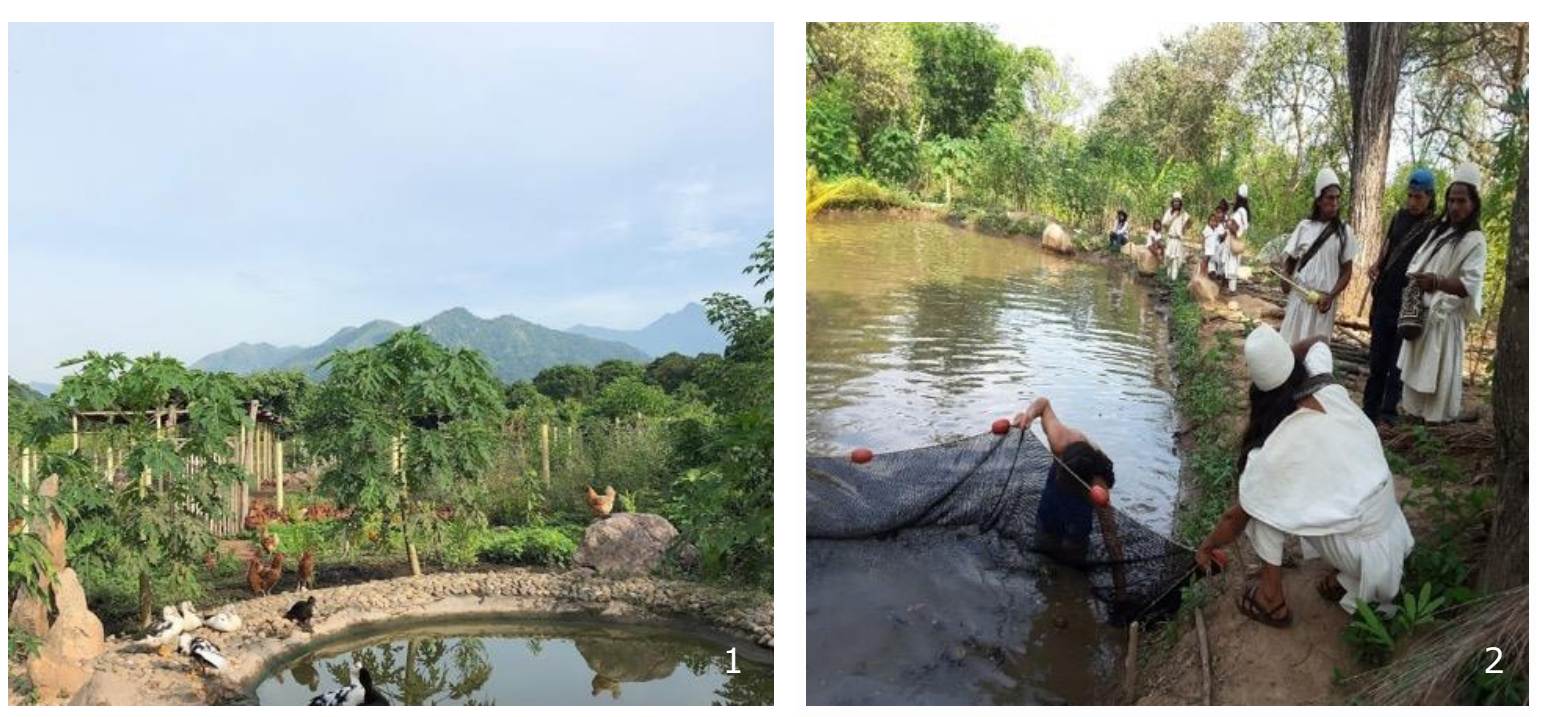

Figure 11 1: Landscape of the integrated agri-aquaculture system in the Arhuacos indigenous community. 2: Fishing activities of the indigenous community. Photography courtesy of UN-ACUICTIO.
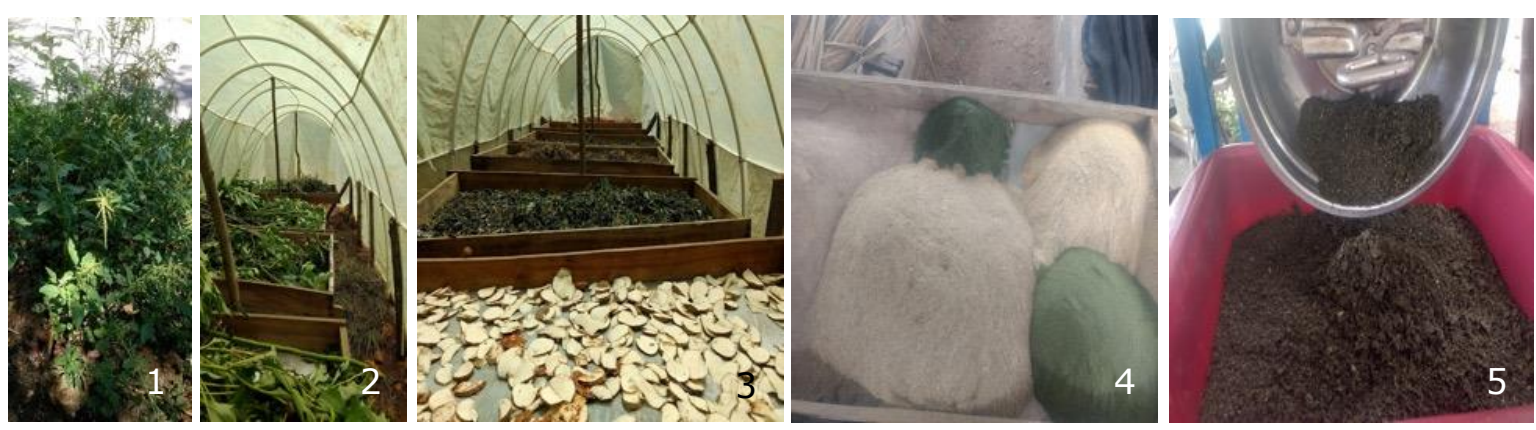

Figure 12 Local fish food production based on the Arhuacos indigenous community garden's resources. 1: Crop, 2: harvest, 3: drying, 4: milled, 5: Processing. Photos courtesy of UN-ACUICTIO.

\subsection{Circular economy policy of the Colombian National Government}

The Colombian Government proposed a national CE strategy, which seeks to promote a new model of economic development that includes the continuous valuation of resources, the closure of material, water, and energy cycles, the creation of new business models, in order, among others, to optimize the efficiency of the production and consumption of materials, and to reduce the water and carbon footprint (Gobierno de la República de Colombia, 2019).

In this strategy, it is estimated that for the period 2020-2028 the productivity of the Colombian economy fell by $1.2 \%$, a similar trend to that of the rest of Latin American economies. These low levels of productivity are reflected throughout all productive sectors, especially in the agricultural and livestock sectors. These sectors consume a large part of the natural resources and occupy large plots of productive lands in the country and require $43 \%$ of the water and contribute $55 \%$ of the greenhouse gases (IDEAM 2018). They also generate approximately $15.5 \%$ of the employment, but only yielded $7.0 \%$ of GDP in 2017 (DANE, 2019).

Additionally, large amounts of biomass represented in agricultural and livestock products are wasted due to lack of knowledge regarding processes and technologies, the lack of access to markets, and the absence of innovation in the generation of value-added products (Bueno, Hoyos \& Mesa- Salinas, 2018). The national CE strategy, thus, has as its target audience companies whose economic activity is part of the productive chains associated with agriculture, livestock production, hunting, forestry, and fishing, as well, waste management and sanitation activities, among others. On the other hand, it is worth mentioning that the national CE strategy is also built on other public policy documents and a 
normative framework of economic and environmental development policies, such as the CONPES 3866 (Departamento Nacional de Planeación, 2016).

\subsection{Waste management and circular economy in Colombia}

According to a World Bank report (2018), 2010 million tons of solid waste are produced annually in the world, and it is estimated that this will increase by up to $70 \%$ by 2050 . Annually, Latin America and the Caribbean will produce 231 million tons of waste (Kaza et al. 2018). This means that globally, 3.4 billion tons need to be managed if adequate measures to mitigate waste production are not taken. The composition of waste is classified into several categories, of which at the global level the largest category is organic waste, which represents $44 \%$ of global waste. Likewise, the level of income in the countries directly influences the amount of organic waste produced, since the percentage of this decreases as income levels increase. While in low-income, upper-middle-income and lower-middleincome countries organic waste represents around 54\%, in high-income countries it represents $32 \%$ (Kaza et al. 2018). Currently, there is no adequate management of organic waste since around $37 \%$ is disposed of in some type of landfill, $33 \%$ is dumped openly, $19 \%$ is recovered through recycling and composting, and $11 \%$ is treated through modern incineration.

The growing generation of waste in Latin America is a very probable future scenario, as consumption and production patterns, extraction of natural resources, and rising social mobility and population growth are expected to continue increasing in the coming years. It is estimated that each Latin American individual produces approximately $1 \mathrm{~kg}$ of garbage per day and that the production of urban waste in Latin America and the Caribbean is 541,000 ton/day, a figure that could reach at least 671,000 ton/day by the year 2050, which represents an increase of $25 \%$ (UN, 2018). According to a report by the UN Environmental Programme, the waste generated in Latin America and the Caribbean represents around $11 \%$ of the world's garbage volume, of which the organic fraction is the one that predominates in the composition of waste, as it represents $50 \%$ and the other $50 \%$ is made up of paper, metal, cardboard, plastic, glass, textile, among others. Following this, the report mentions that as there is no proper management and places suitable for the final disposal of waste, they are lost by $90 \%$ since only $10 \%$ of these are used through recycling or other waste techniques recovery (UN, 2018).

In Colombia, the generation of solid waste is associated with population growth and globalization that generates a consumer culture resulting in the lack of proper management of solid waste. Due to this, the indiscriminate disposal of waste in sanitary landfills translates into a loss of nutrients and environmental pollution (SSPD, 2018). It is estimated that the production of solid waste in Colombia is around 12 million tons per year, of which organic waste reaches 55\%. Likewise, in each department of the country, the amount of waste varies, being in Bogotá 6,366 ton/day (20.55\%), Valle del Cauca 3,592 ton/day (11.60\%), Antioquia 3,575 tons/day (11.54\%) and Atlántico 2,387 ton/day ( $7.71 \%)$ (DANE, 2018). Environmental Impact Assessment studies that were executed are only descriptive, which means that the environmental management plans are deficient and also are not applied properly due to the lack of effectiveness in monitoring their implementation by environmental authorities since they do not establish control mechanisms such as impact and management indicators that allow regulation (SSPD, 2018). Although currently users can use waste managers that comply with the regulations, the purpose is not only to comply with the law, but to go a little further and understand the complete cycle of this waste in order to know and apply ithe best strategy (Colombia Productiva, n.d.). In any case, Colombia is still quite incipient in the transition from a linear to a circular economy.

\subsection{Approaching current circular agriculture practices among Colombian peasants}

To describe current circular agriculture activities practiced by Colombian peasants we carried out structured interviews with 43 small-scale fish producers enquiring fish-production related practices. First of all, we found that peasants usually combine fish production with other activities such as traditional agriculture, and production of livestock, poultry, pigs, sheep and goats. Some of the crops 
introduced by these peasants involve green banana, orange, avocado, cassava, sugar cane, passion fruit and vegetables. Other activities are tourism and exhibition of different farm animals. However, it is important to highlight that not all the interviewed fish producers develop agricultural activities as the unique source of income generation. Most of them work on other activities to complete a regular and sustainable income. This represents a relevant issue which is impacting and transforming traditional family farming and that must be considered in any economic model.

Small-scale fish farmers produce a variety of fish depending on the environmental conditions and the demand of the market. These species include freshwater pompano (Piaractus brachypomus), bocachico (Prochilodus magdalenae and Prochilodus reticulatus), pirarucu (Arapaima gigas), arawana (Osteoglossum bichirrosum), tilapia (Oreochromis sp.), Nile tilapia (Oreochromis niloticus), carp (Cyprinus carpio) and yamú (Brycon amazonicus). Water used in these production systems is mainly provided by rivers, natural water sources, water grants by local authorities or water wells. To protect water sources, peasant fish farmers used to sow native trees in the riverside and to recirculate water through filtering systems and water treatments (if funding sources allow). Residual water is commonly used as fertilizer and in other cases it is directly sent to small plots. Sub products of the fish farming activities (such as viscera, bones and fish manure) are used to feed pigs or poultry and as crop fertilizer.

These fish producers use commercial feed as the main source of fish feed; however, other alternatives are being tested such as rice bran, taro (Alocasia macrorrhiza) and insects caught by using lights on the ponds. Between $10 \%$ and $40 \%$ of the production is being used for internal consumption while the rest is sold at local markets. Most of these projects are self-financed while others, specifically those addressed to the reincorporation of ex-insurgents, include funding by international cooperation agencies.

Regarding current experiences of insect farming for feeding fish, apart from the traditional use of lamps over the ponds to catch insects in the night, there is not enough knowledge about the production of insects. Other experiences include the production of earthworms in an artisanal way. Regarding prejudices and common assumptions on insect production, small farmers recognize that there is no relevant information and people commonly associate flies with low hygiene and transmission of illness.

For agroecological practices, peasant farmers commonly use organic fertilizers (compost and poultry manure) produced on their farms, efficient forest micro-organisms to increase soil fertility, care and responsible management of the water sources and the use and promotion of traditional and native seeds.

As constraints for the economic development of their productive initiatives, the interviewed fish producers identified the lack of technology and knowledge, difficulties in access to land ownership and financial services and loans, high .prices of animal feed, difficulties in accessing markets, lack of government support and high costs of energy.

As we see, current circular agriculture activities are based on former traditional family farming knowledge rather than on specific training developed by an educational institution. The role of the state, then, seems to be weak as it has not been decisive in disseminating this knowledge. Peasant-topeasant methodology, on the contrary, has been the common way of acquiring such knowledge. As these practices are not scientifically supported at all, they need to be strengthened by increasing their rigurosity and variety. Considering the multiplicity of circular agriculture activities, peasant farming is still lacking additional knowledge.

Furthermore, the lack of distribution of land in Colombia continues being one of the main obstacles to develop peasant farming. While this issue is not being solved, peasant family farming is being performed mostly under scarcity conditions which make it difficult to keep peasant culture in different regions. This represents an opportunity to explore innovation in circular agriculture as peasants are willing (and needed).

to acquire and put new knowledge into practice. The continuity of the social conflict in rural areas, which promotes internal displacement and dispossession of land, seems also to be a factor that can impede future scenarios of circular agriculture. 


\section{Towards a model of circular economy: Agroecological Insect-Fish Farming}

The pathway proposed by the authors in this document is grasped in what we have called "Agroecological Insect Fish Farming" (AIFF). We used the term "agroecology" considering its holistic view which already includes the concept of $C E$. This section then analyses the pathways toward a transition from linear to $\mathrm{CE}$, from the lenses of agroecology and CE, followed by a SWOT analysis to describe the Colombian context and how this affects the development of insect farming initiatives. After that, we identify the connection of agroecological insect-fish farming in the context of the SDGs, followed by a proposal of principles of CE. Then we explore the possibilities of income generation through the participative development of a Lean Canvas model and show the production cost structure to be more precise. Finally, we propose the general features of AIFF based on the theoretical frame proposed in the literature review.

\subsection{Is there a pathway?}

Transdisciplinary analysis of real-world transitions toward agroecological systems has embraced the science of complexity in order to understand emerging properties such as resilience and adaptive capacity (Tittonell, 2020). Figure 13 shows a theoretical framework for understanding changes in the relationship between ecosystem services and farming intensity in distinct transition scenarios. Traditional or peasant agroecosystems, often lacking the capital and infrastructure to add value or manage landscapes, can be pushed out in favor of more industrial, entrepreneurial systems.

Alternatively, they can transition toward more ecologically complex, resource-efficient peasant agroecological systems, wherein they develop degrees of distance from market forces, also known as "farming economically" (van der Ploeg, 2008).

There is not a single pathway to a CE. Instead, there are many different trajectories that can lead farming systems toward more sustainable use and resource loops. Agroecology emphasizes contextspecific practices based upon principles such as synergy and diversity. Figure 14 shows potential pathways and the evolving relationship between resource circularity and income in agroecological insect fish farming trajectories. 


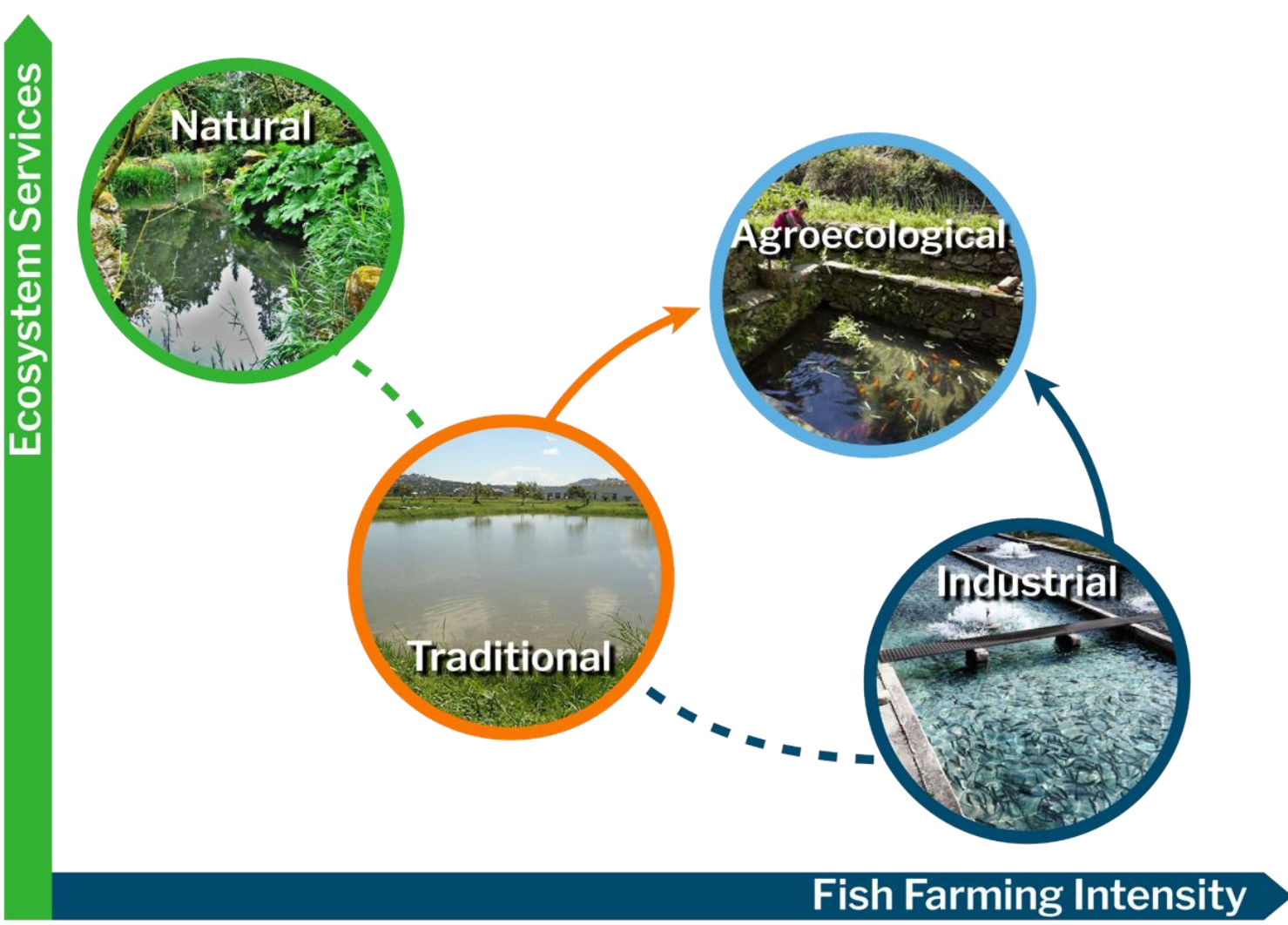

Figure 13 Relationships between ecosystem services and farming intensity. Ecosystem services are measured in the $Y$ axis and farming intensity is represented in the $X$ axis. Different routes between the stages can be presented. Dot lines represent these possible routes. Adapted from Tittonell (2020).

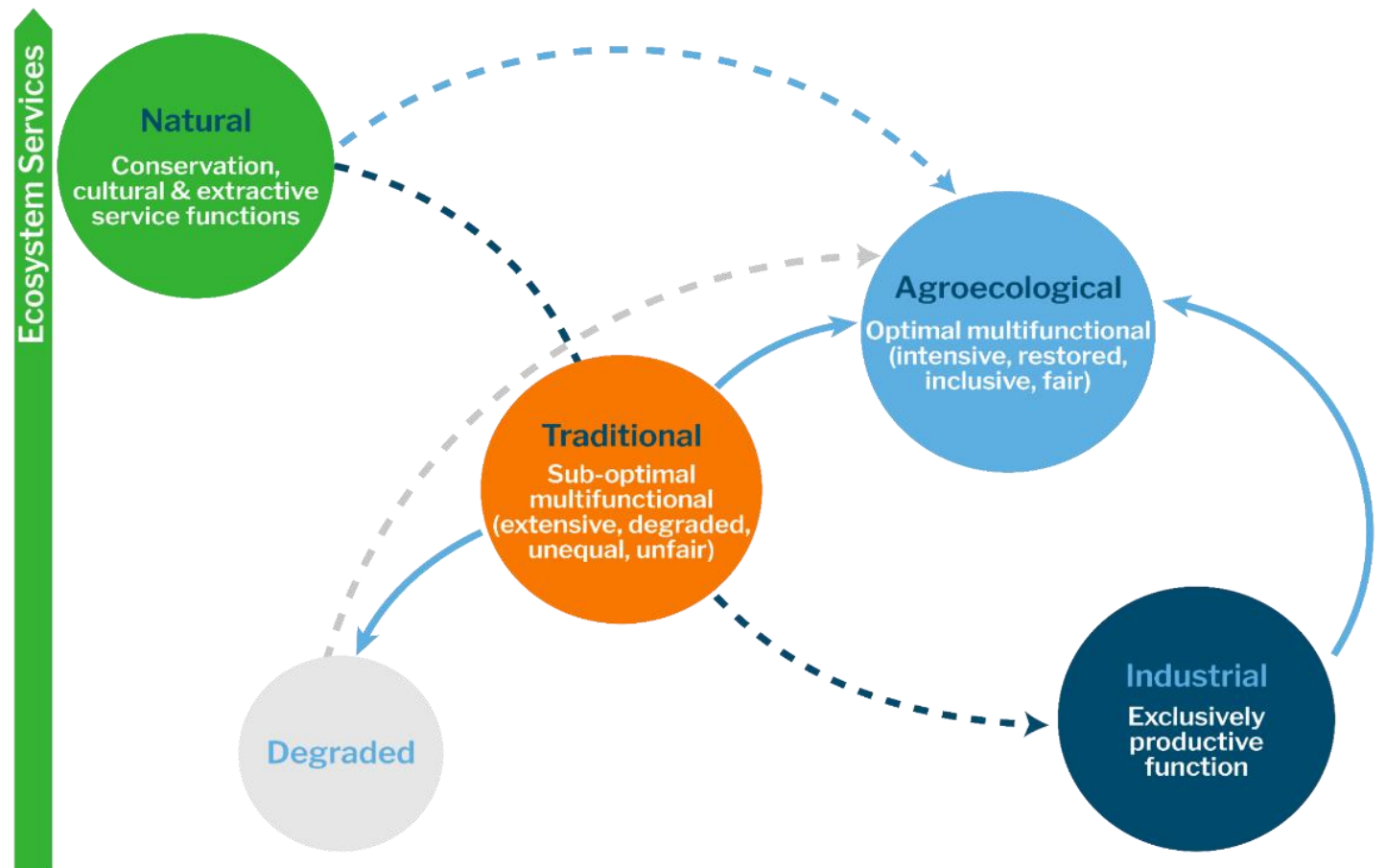

Figure 14 Analogous scheme representing the relationship between ecosystem services and fish farming intensity. Elaborated by authors. 


\subsection{SWOT analysis for insect farming in aquaculture in Colombia}

Pros and cons of the use of insect farming in aquaculture in Colombia are assessed by using a SWOT analysis to identify the key factors that could support or impair the development of insect farming in Colombia as protein source for the aquaculture sector. All observations and inferences suggested are based on the data gathered, on the previously documented literature and on the authors' experience. The following SWOT analysis focusses on insect farming in Colombia.

\subsubsection{Strengths}

- Climate conditions

- Wide availability of substrates and organic waste

- $\quad$ Easy access to materials to build local infrastructure

- Support from academia

- New Colombian insect-producing companies

- Constantly growing fish production sector in Colombia

- $\quad$ Current indigenous and traditional knowledge among peasant farmers

\subsubsection{Weaknesses}

- Low current insect production rate

- $\quad$ Lack of processing technology for insect farming

- Gaps in knowledge of insect production: rearing, processing, animal feed formulation

- Lack of access to sources of investment, especially for peasant farmers

- $\quad$ Lack of government support

- Lack of accessing roads

- Lack of access to technical, Information and Communication Technologies (ICTs) and scientific knowledge in rural areas

\subsubsection{Opportunities}

- Inclusive business: improving livelihood and food security of peasant communities

- $\quad$ Socio-economic reintegration of vulnerable communities

- $\quad$ Novel animal production systems with added values

- Innovative conceptualization: CE, disruptive innovation, novel protein alternatives, solidarity and agroecology.

- High willingness of peasant farmers to be involved in insect farming and innovative business

- Peace construction scenario in the territories which could allow the immersion of communities in innovative productive initiatives.

- $\quad$ Current public policy of CE

- The creation of a normative of good practices of insect production

- $\quad$ Current fluctuation of the dollar rate exchange that leads to excessive costs of commercial feed which may be reduced by insects as fish feed

- $\quad$ Other technologies oriented to implement CE alternatives to reduce organic waste may be more expensive than those which include insects

\subsubsection{Threats}

- Social and cultural stigma against the use of insects and against the replacement of traditional fish feed.

- Excess of legislative regulations addressed to undermine artisanal ways of production and in favor of intensive and industrial production or that would not be adjusted to local realities.

- $\quad$ Existing war and illegal activities in rural areas with gangster-like control over territories

- Risks of monopoly of the insect farming sector 


\subsection{Agroecological Insect-Fish Farming and its relation with the SDGs}

The implementation of organic-waste-based production of insects, such as the BSF, mainly by small producers, can have more advantages than disadvantages. The use of waste generated in their own production systems that facilitates a circular approach either for on-farm agriculture or in the local community, can contribute to reducing dependence on external inputs. This not only benefits the producer individually but can also contribute to their livelihood and to several SDGs as summarized in Figure 15.

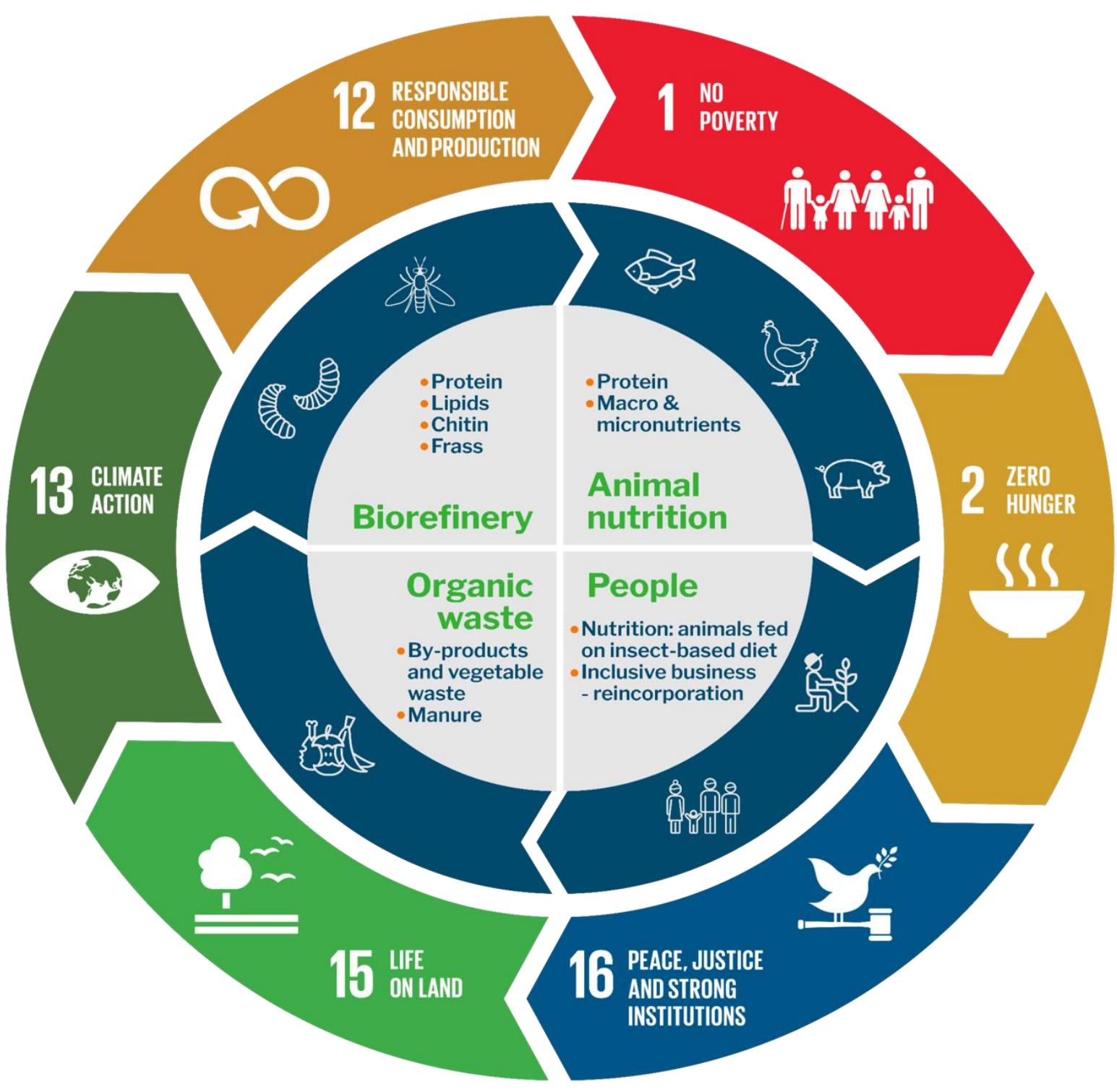

Figure 15 Agroecological Insect-Fish Farming in Colombia and its relation with the Sustainable Development Goals of the UN 2030 agenda. 


\subsection{Circular economy principles to develop agroecological insect fish farming}

The CE model has been explored by many sectors and industries trying to leave behind the "takemake-dispose" paradigm and transform it into a new one based on a circularity which avoids and discards the consumption of finite resources, uses renewable elements to make the cycle and provides a restorative and regenerative economic model. More than an economy, this is a concept based on the next three principles described below and shown Figure 16.

- Principle 1 - Inputs: Preserve and enhance natural capital by controlling finite stocks and balancing renewable resource flows. Fish farming uses various ingredients, materials and components in the process that can be supplied through circularity. For example, using tights that are made from recycled plastic to cover lakes, using water that comes from the same system after being cleaned, and using alternative protein sources to feed fish such as BSF larvae which can be produced on organic waste streams next to the fish production system and which has a high protein level. Reducing the traditional protein source by using BSF larvae can reduce the feed cost in the process up to up to $31 \%$ as shown in the Table 5 .

- Principle 2 - Processes: Optimize resource yields by circulating production components and materials in both technical and biological cycles. Fish farming being a biological production system, uses many environmental resources like water, air, sunlight and land. It generates many waste streams. Fish entrails, fish manure, and organic waste from kitchen activities and nearby crops. All kinds of organic waste can be disposed of through feeding it to BSF larvae, which is a good way to reduce and re-use organic waste to produce one of the sources for fish feed. This transformation mixes a biological compound with a technical use based on this principle. Sharing this technology is one of the advantages used by communities and organizations. BSF farming is designed on a scalable concept, so that it can be multiplied in other regions and easily adopted thus implementing a CE.

- Principle 3 - Outputs: Foster system effectiveness by revealing and phasing out negative externalities. Adopting the CE model in fish farming is the first step to re-think the way to produce a high-quality product for the local population that needs food for life and helps local communities in social, cultural, economic and environmental aspects. 


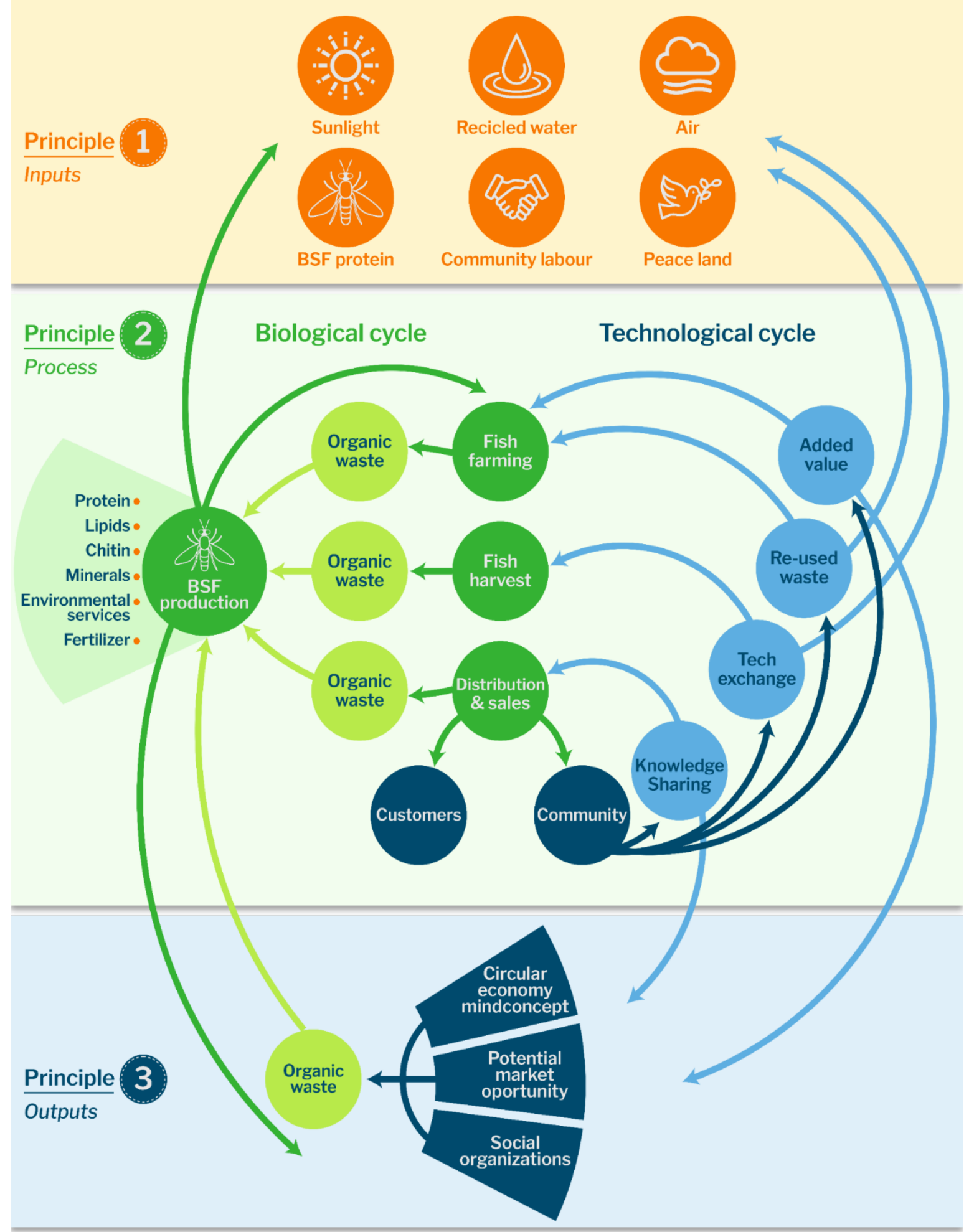

Figure 16 General Description of the Agroecological Insect-Fish Farming model.

The integration of BSF farming into fish production is an opportunity to be part of the change and resolve the problem of waste generation, human population growth and the shortage of environmental resources.

BSF production matches perfectly with the features of CE and agroecology mentioned above (Figure 17): waste is phased out, BSF compost is easily used into the soil and fish farming directly.

Diversity strengthens society, especially when adopted by peasant communities. Communities can modify production processes in their territories according to their own needs. Similar to agroecological systems, this model has a higher survival rate than others due to its diversity and existence of different scale businesses. Renewable energy applied in CE processes helps to implement BSF systems in different settings but also empowers peasant economy by raising profitability. System thinking as the base of the model -like other biological cycles. All people involved in the process 
should think in terms of CE as a complete system in which all the elements of the system play an important role. Profits should reflect real costs - as will be shown in the project Insects for Peace. Externalities should be considered and subsidies should be taken away.

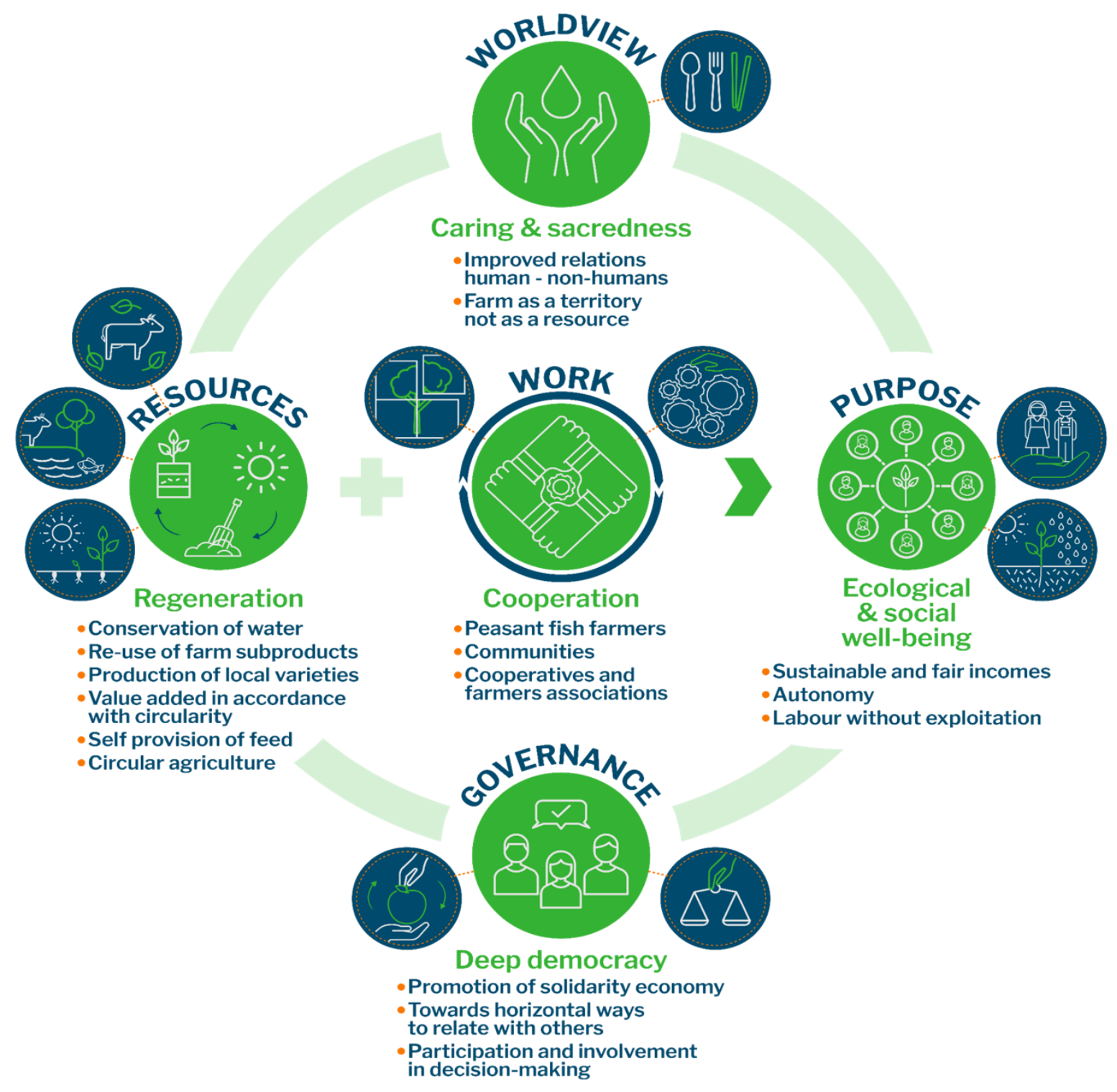

Figure 17 Circular economy principles applied to Agroecological Insect-Fish Farming in Colombia.

\subsection{Income generation possibilities for Agroecological Insect-Fish Farming}

In order to analyze the economic impact of replacing commercial feed with BSF larvae based on a circular approach, we use the Lean Canvas Model (Joyce \& Paquin, 2016) for small scale fish farmers. The Lean Canvas Model is an adaptation made by Ash Maurya from the Canvas Business Model proposed by Alex Osterwalder which analyses a different point of view of several business models and identifies the basis of each project by transforming it into key assumptions ("Lean Canvas |

LEANSTACK," n.d.). This exercise helps to understand the framework, the problem that is being solved by the project, the competition, the different advantages shown to the potential customers, and the way to receive revenues and the cost related to the activities.

In Table 3 we show the Lean Canvas for the Icononzo project developed by ex-guerrilla members producing tilapia fish fed with BSF larvae as an alternative protein source for the commercial feed. 
This exercise was made through a participatory workshop with 5 individuals involved in the project by following several steps:

1. Identifying three main problems which must be solved by the project This can show customer segments describing their principal characteristics. Other alternatives and solutions are also described if solutions proposed are not available. This step could help listing early adopters of the solution such as local visitors, family and friends.

2. Defining the unique value proposition. This is the heart of the project at the moment the business project is written. It describes the features of the CE applied to a fish farming process.

3. Determining the solution by the aspects, concepts and flows shown in the first step. The solution (added value fish) needs to be transferred to potential clients through a list of options. It refers to different channels where the fish is available for the potential customers.

4. After analysing how the customers can use the solution, the economic flow can be solved by assessing the costs and benefits related to the activity.

5. Key metrics describe the aspects needed to define the status of the project and are the potential parameters to be measured. They can identify how BSF production performance is going on and whether this process is being useful in terms of reducing feeding costs and adding value to a differential product in the market.

6. Describing differences from competitors to identify whether the customers select this solution instead of others.

Table 3 Lean Canvas Model* for AIFF ex-insurgents members of the Icononzo project**.

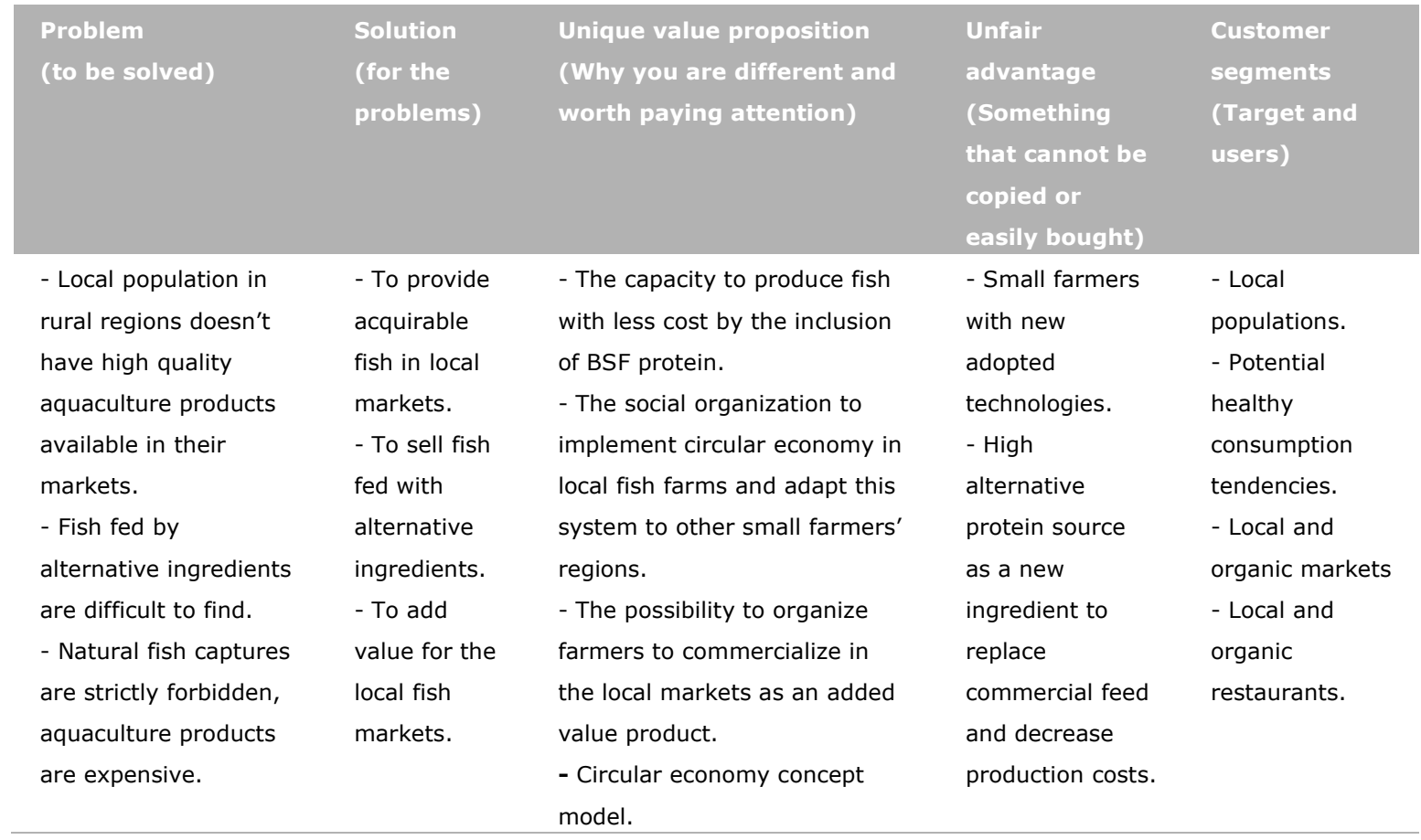

\begin{tabular}{|c|c|c|c|}
\hline Existing Alternatives & $\begin{array}{l}\text { Key metrics (How you measure your } \\
\text { business) }\end{array}$ & $\begin{array}{l}\text { Channels (Your } \\
\text { path to } \\
\text { customer) }\end{array}$ & $\begin{array}{l}\text { Early adopters } \\
\text { (Your ideal } \\
\text { customer) }\end{array}$ \\
\hline $\begin{array}{l}\text { - Poultry, swine and } \\
\text { other kind of protein in } \\
\text { the market. } \\
\text { - Natural fish captures. }\end{array}$ & $\begin{array}{l}\text { - Commercial feed replacement } \\
\text { - BSF larvae production in } \mathrm{kg} \\
\text { - Disposed organic waste in } \mathrm{kg} \\
\text { - Conversion of organic waste into BSF } \\
\text { larvae } \\
\text { - BSF development time }\end{array}$ & $\begin{array}{l}\text { - Local markets } \\
\text { - Social media } \\
\text { - Social projects } \\
\text { and meetings. }\end{array}$ & $\begin{array}{l}\text { - Local farmers } \\
\text { - Social workers } \\
\text { - Families next to } \\
\text { the fish farmers }\end{array}$ \\
\hline
\end{tabular}




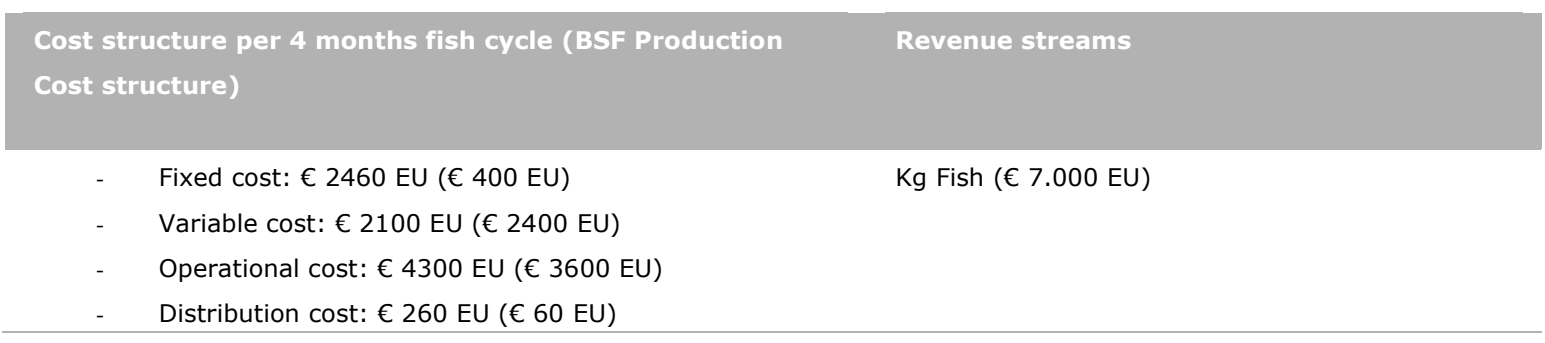

*Lean Canvas is adapted from The Business Model Canvas (BusinessModelGeneration.com) and is licensed under the Creative Commons Attribution-Share Alike 3.0 Un-ported License

**BSF in Aquaculture systems in Icononzo -Tolima Date: 2021

\subsection{Production costs structure}

To analyse the direct impact of the inclusion of alternative raw materials (such as BSF larvae) as a protein source to decrease the costs related to fish feed, it is necessary to show the financial balance of a case study in a fish farm where this innovation has been implemented. The fish farm analysed for this cost structure was the pilot plant located in Icononzo-Tolima of the Insects for Peace project. All costs and revenues are expressed for an AIFF with 7000 fish and $1400 \mathrm{~kg}$ of BSF production capacity each 4 months (tilapia cycle). Table 4 shows the costs structure of the BSF production, it includes expert advise, production services, administration costs, maintenance and depreciation machine costs for a production capacity of $350 \mathrm{~kg}$ per month. Overall, BSF costs amount to $0.94 €$ per $\mathrm{kg}$ tilapia produced.

In Table 5 the total net cash flow (the amount of money that is still available after selling the products and paying the total costs related to the economic activity) is shown. The table shows the difference between using a linear model (without BSF) and a CE model based on the production of BSF larvae. The linear approach reduces the possibility to grow and replicate similar projects in other regions and in other communities due its low net cash flow, however, the CE model gives an opportunity to include various outcomes and costs by giving higher revenues up to $44 \%$ as shown in Table 5 . One of the elements that shows the different way of managing costs is the labour payment. When the farm includes BSF production, it has the possibility to pay labour costs to the person who is doing the BSF production, but when the farm uses a traditional linear system, there is no opportunity to generate a new payed labour related to the fish farming.

Table 5 also shows the balance per production cycle ( 4 months is the production time of the tilapia in the juvenile and growth phase), which suggests that using BSF larvae may produce a return rate up to $45 \%$ considering that total sales are $€ 7500$ and the cost associated to its production is around $50 \%$ of it. When BSF is included in the fish farm, the final price of the fish ( $€ 1 /$ fish) on the market is higher than without BSF production ( $€ 0.71 /$ fish). Additional to that, as mentioned before, one of the byproducts of the BSF transformation process is the fertilizer, which can be used for crops providing higher quality to fruits and vegetables (Barragan-Fonseca et al. 2020a) and so, improving profits for the peasant family. In the table, BSF costs are shown as the monthly cost of the activity related to the production of BSF larvae in the project Insects for Peace located in Icononzo, Tolima, Colombia. Future higher incomes could be used for investing in new technological developments to strengthen the circularity adopted for the AIFF model. Further AIFF systems could compare different production capacities and needs in order to develop the transition from a linear system to a CE. 
Table 4 BSF production costs structure of the Icononzo project per fish cycle (4 months).

\begin{tabular}{|c|c|c|}
\hline Expenditure & \multicolumn{2}{|c|}{ Value (Euro) } \\
\hline Labour payment & $€$ & 400 \\
\hline Consultants/Contractors & $€$ & 100 \\
\hline Organic Waste transport & $€$ & 80 \\
\hline Water & $€$ & 16 \\
\hline Machine depreciation & $€$ & 108 \\
\hline Marketing & $€$ & 20 \\
\hline Machine maintenance & $€$ & 60 \\
\hline Telephone/Internet & $€$ & 60 \\
\hline Accy/payroll/bank & $€$ & 200 \\
\hline Total Cash OUT & $€$ & 1.320 \\
\hline Production capacity $(\mathrm{kg})$ & 14 & \\
\hline BSF cost per $\mathrm{Kg}$. & $€$ & 0.94 \\
\hline
\end{tabular}

Table $5 \quad$ Fish production; financial balance with and without BSF per 4 months.

\begin{tabular}{|c|c|c|c|c|}
\hline \multirow{2}{*}{$\begin{array}{l}\text { Income for } 7.000 \text { fish } \\
\text { Fish product revenue }\end{array}$} & \multicolumn{2}{|c|}{$\begin{array}{l}\text { With BSF (circular } \\
\text { model) EURO }\end{array}$} & \multicolumn{2}{|c|}{$\begin{array}{l}\text { Without BSF (linear } \\
\text { model) EURO }\end{array}$} \\
\hline & $€$ & 7.000 & $€$ & 5.000 \\
\hline Other products revenues & $€$ & 500 & $€$ & 200 \\
\hline TOTAL INCOME & $\mathbf{c}$ & 7.500 & $\boldsymbol{c}$ & 5.200 \\
\hline \multicolumn{5}{|l|}{ EXPENDITURE } \\
\hline Consultants/Contractors & $€$ & 60 & $€$ & 60 \\
\hline Feed cost & $€$ & 1.200 & $€$ & 2.700 \\
\hline Service costs & $€$ & 20 & $€$ & 20 \\
\hline Distribution & $€$ & 200 & $€$ & 200 \\
\hline BSF cost* & $€$ & 1.320 & $€$ & - \\
\hline Telephone/Internet & $€$ & 60 & $€$ & 60 \\
\hline Accy/payroll/bank & $€$ & 320 & $€$ & 320 \\
\hline Total Cash OUT & $€$ & 4.010 & $€$ & 4.190 \\
\hline Net Cash Flow & $€$ & 3.490 & $€$ & 1.010 \\
\hline Closing balance & $€$ & 3.490 & $€$ & 1.010 \\
\hline
\end{tabular}




\section{$7 \quad$ Conclusions and recommendations}

The constant growth of Colombian aquaculture is given by the increase in productivity and in the number of producers. However, a large part of fish producers have limited resources, and would benefit from alternative feed ingredients for the partial or total substitution of commercial feeds that currently need high investments while minimizing final net income. The transition from linear to circular aquaculture in Colombia and Latin America requires a local analysis of the actors (stakeholders) that can potentially intervene so that the system is successful and that it adjusts to geographic, regulatory and socio-economic conditions.

Considering the former arguments, and the importance of decreasing the dependence on external inputs (such as raw material and balanced feed) of subsistence aquaculture systems it is fundamental to develop and implement appropriate circular agriculture practices - which include insects as fish feed - in peasant and indigenous communities. Local fish feed production is urgent, because most of small fish-farmers rely on commercial feeds that are expensive and scarce in some regions of the country. Some producers mix local resources with commercial feed, but do not follow technical guidelines that can guarantee adequate fish performance, economic benefits and low environmental impact. Fostering circularity, whose concepts are already incorporated in the agroecological principles, might allow the improvement of income of peasant families and the conservation of nature in rural areas.

The transition to a sustainable organic waste management through insects may establish the best way to put Agroecological Insect-Fish Farming (AIFF) into practice in a local scenario. Scholars, in an interdisciplinary way, must observe the best way to manage organic waste in cities involving peasant communities living in close-by rural areas in the production chain of insects as feed, and insects-based fertilizers.

Experience shows that this transition cannot be merely technological; by nature, it is multidimensional and requires active participation by social actors. In this sense, the role of peasant producers in embracing and carrying out circular economy practices through agroecological transitions is fundamental. The use of insects to produce animal feed is not a socially neutral technology-it favours local economies by reducing production costs and augmenting the locally-produced share of total value. However, if these technologies fall into the mainstream economic system of patents, monopolies and transnational capitalist relations, there will be no benefit to small farmers and peasants. It is vitally important that these sectors appropriate the knowledge and skills of insect production, in order to capture that value and build more autonomous food systems. Insect rearing as a contribution to making animal feed, for producing pest repellents and fertilizers, is a major opportunity for peasants and small farmers to reduce the dependencies inherited from the Green Revolution, and to (re)develop and design their own knowledge systems.

Considering the current peasant economy in Colombia and more specifically, the rural context still pierced by different forms of violence, AIFF could be seen as an alternative approach to improve living conditions of peasant families and to reduce, somehow, their involvement in the coca-related economic activities. Perhaps, it could be seen as an alternative productive initiative to substitute coca crops. The promotion of AIFF among peasant communities in former conflict areas, could support current endeavours to build peace and to strengthen the reincorporation process of the ex-insurgent population.

The state involvement in legislation and promotion of insect production and circular economy is desired only if it supports local and peasant economies. For this, research and productive endeavours must be developed in local settings with technologies and knowledge that are appropriate for peasant communities and producers. We strongly recommend that, considering the current political and conflictive environment of Colombian society and especially traditional state behaviour (bureaucratic and corrupted), efforts to implement and develop the AIFF model should be preferably carried out to directly support peasant communities and under the framework of local solidarity economy or cooperative development.

From an economic point of view, using BSF to develop a circular economy model for aquaculture production, opens the possibility to differentiate products from other suppliers adding value to the ones that have been produces into an AIFF model. It is also related to the cost structure of the model, 
assuming the feeding cost of the fish from the BSF production cost, paying salaries and land rent costs. It partially replaces the use of commercial fish feed, upcycling the waste which must be disposed of some other way.

The proposed model for the transition to an AIFF is theoretical and based on limited information collected with aquaculture or insect producers, as well as a first experience with ex-combatants producing tilapia with BSF as a component of the feed. More information based on studies is required and pilot experiences that gradually incorporate insects in feed for different species of fish such as native South American species such as carp and trout. This will generate more information on each of the components of the circular economy, which will further refine the proposed model.

Open dialogues and exchange of knowledge with aquaculturists and insect producers is needed to increase current knowledge about the possibility of incorporating alternative raw materials for fish production, as well as the knowledge and appropriation of the proposed AIFF model. It is also necessary to strengthen collaboration between public and private entities in Latin American countries, to propose productive models of AIFF for the region, adapting it in local contexts. 


\section{Acknowledgements}

The authors thank Santiago Vergara and Laura Suárez who helped to carry out the insect producers' surveys. We also thank to the promotors of ECOMUN who carried out the ex-insurgents' surveys. We also thank the Ministry of Agriculture, Nature and Food Quality of the Netherlands for providing funds for this study. 


\section{References}

Anderson, C.R., Bruil, J., Chappell, M.J., Kiss, C., \& Pimbert, M.P. (2019). From transition to domains of transformation: getting to sustainable and just food systems through agroecology. Sustainability, 11, 5272.

Ahmed, N. (2007). Economics of aquaculture feeding practices. Bangladesh. In M.R. Hasan (ed.) (2007). Economics of aquaculture feeding practices in selected Asian countries. FAO Fisheries Technical Paper. No. 505. Rome, FAO. pp. 33-63.

Anokyewaa, M. A., \& Asiedu, B. (2019). Economic analysis of small-scale aquaculture enterprise in ghana; a case study of sunyani municipality. Asian Journal of Fisheries and Aquatic Research, (March), 1-12. https://doi.org/10.9734/ajfar/2019/v3i230031

Aguilar-Manjarrez, J. \& Flores Nava, A. (2020). Impacto de la pandemia sobre la acuicultura en América Latina y el Caribe. Presentación en foro virtual: Perspectivas de salud y producción animal frente a la crisis colombiana, sesión 2: COVID-19 ¿Oportunidad para reinventar la acuicultura colombiana?. 23 de julio de 2020. http://medicinaveterinariaydezootecnia.bogota.unal.edu.co/fileadmin/user_upload/MemoriasSesio n2ForoAcuicola.pdf

Baki, B., \& Yucel, S. (2017). Feed cost/production income analysis of seabass (Dicentrarchus labrax) aquaculture. International Journal of Ecosystems and Ecology Sciencias, 7(4), 859-864. http://uo-i.org/1.01/ijees/85653234

Barragán-Fonseca, K. Y., Barragán-Fonseca, K. B., Verschoor, G., van Loon, J. J. A., \& Dicke, M. (2020a). Insects for peace. Current Opinion in Insect Science, 40, 85-93. https://doi.org/10.1016/j.cois.2020.05.011

Barragán-Fonseca, K., Cortés Urquijo, J., Dicke, M., \& Quintana, A. P. (2020b). South-south inspiration to connect SDG2 and SDG16 in former conflict areas: Promoting sustainable livelihoods of ex-insurgents in Colombia by insect farming. (Report / Wageningen Livestock Research; No. 1289). Wageningen Livestock Research. https://doi.org/10.18174/539034

Barragan-Fonseca, K.B., Dicke, M., \& van Loon, J.J.A. (2017). Nutritional value of the BSF (Hermetia illucens L.) and its suitability as animal feed-a review. Journal of Insects as Food and Feed, 3(2), 105-120.

Barrios, E., Gemmill-Herren, B., Bicksler, A., Siliprandi, E., Brathwaite, R., Moller, S., Batello, C. \& Tittonell, P. (2020). The 10 Elements of Agroecology: enabling transitions towards sustainable agriculture and food systems through visual narratives. Ecosystems and People, 16(1), pp.230247.

Biovision (2019). The Agroecology Criteria Tool (ACT) methodology. https://www.agroecologypool.org/methodology/

Borrello, M.; Lombardi, A.; Pascucci, S. \& Cembalo, L. The seven challenges for transitioning into a bio-based circular economy in the agri-food sector. Recent Pat. Food Nutr. Agric. 2016, 8, 39-47.

Bortolini, S., Macavei, L. I., Saadoun, J. H., Foca, G., Ulrici, A., Bernini, F., .. \& Maistrello, L. (2020). Hermetia illucens (L.) larvae as chicken manure management tool for circular economy. Journal of Cleaner Production, 262, 121289.

Bueno, J., Hoyos, J., \& Mesa- Salinas, C. (2018). Reporte sobre la productividad del sector agroalimentario de Colombia, Australia y Nueva Zelanda como referentes para su transformación. Embajada de Colombia en Australia. http://ledslac.org/wp-content/uploads/2020/03/2_ENECVersio\%CC\%81n-final-24-02-20-1_compressed.pdf

Cadinu, L. A., Barra, P., Torre, F., Delogu, F., \& Madau, F. A. (2020). Insect rearing: Potential, challenges, and circularity. Sustainability, 12(11), 4567.

Calle-Collado, Á., D. Gallar, \& J. Candón. 2013. Agroecología política: La transición social hacia sistemas agroalimentarios sustentables. Revista de Economía Crítica, 16:244-77.

Caswell, M., Maden, R., McCune, N., Méndez, E., Bucini, G., Anderzén, J., Izzo, V., Hurley, S., \& Gould, R (2021). Amplifying Agroecology in Vermont: Principles and Processes to Foster Food Systems Sustainability. Project: Advancing Trandisciplinary and Participatory Action Research (PAR) in Agroecology 
CEPAL \& FILAC. (2020). Comisión Económica para América Latina y el Caribe (CEPAL)/Fondo para el Desarrollo de los Pueblos Indígenas de América Latina y el Caribe (FILAC). "Los pueblos indígenas de América Latina - Abya Yala y la Agenda 2030 para el Desarrollo Sostenible: tensiones y desafíos desde una perspectiva territorial", Documentos de Proyectos (LC/TS.2020/47), Santiago, 2020.

Chayanov, A. (1986). On the theory of non-capitalist economic systems. In: The theory of peasant economy (pp. 1-28). Madison: University of Wisconsin Press.

Chia, S. Y., Tanga, C. M., van Loon, J. J., \& Dicke, M. (2019a). Insects for sustainable animal feed: inclusive business models involving smallholder farmers. Current Opinion in Environmental Sustainability, 41, 23-30.

Chia, S. Y., Tanga, C. M., Osuga, I. M., Alaru, A. O., Mwangi, D. M., Githinji, M. \& Dicke, M. (2019b). Effect of dietary replacement of fishmeal by insect meal on growth performance, blood profiles and economics of growing pigs in Kenya. Animals, 9 (10): 705.

Chia, S. Y., Macharia, J., Diiro, G. M., Kassie, M., Ekesi, S., van Loon, J. J., \& Tanga, C. M. (2020). Smallholder farmers' knowledge and willingness to pay for insect-based feeds in Kenya. PloS one, 15(3), e0230552.

CIDSE (Cooperation Internationale por le D'eveloppement et la Solidarit'e) (2018). The principles of agroecology: towards just, resilient and sustainable food systems: https://www.cidse.org/wpcontent/uploads/2018/04/EN The Principles of Agroecology CIDSE 2018.pdf

Colombia Productiva. (n.d.). Economía circular. Una forma diferente de hacer negocios sustentables. https://www.colombiaproductiva.com/ptp-capacita/publicaciones/transversales/guia-empresarialde-economia-circular/200310-cartilla-economia-circular

Comisión Histórica del Conflicto y sus Víctimas (2015). Contribución al entendimiento del conflicto armado en Colombia. Ediciones Desde Abajo.

Departamento Nacional de Planeación (2016). Política Nacional de Desarrollo Productivo. República de Colombia - CONPES 3866. Consejo Nacional de Política Económica y Social. https://www.mincit.gov.co/minindustria/temas-de-interes/politica-dedesarrolloproductivo/documento-conpes-3866.aspx

Crowley, E. (2020). Impulsar la acuicultura de pequeña escala. https://www.aqua.cl/columnas/impulsar-la-acuicultura-de-pequena-escala/)

Dirección. (2020). Geopolítica de la pandemia de COVID-19. Geopolítica(s). Revista de estudios sobre espacio y poder, 11(Especial), 11-13. https://doi.org/10.5209/GEOP.69137

DANE (2018). Boletín Técnico. Cuenta Ambiental y Económica de flujos de materiales-residuos sólidos del 2017-2018.

https://www.dane.gov.co/files/investigaciones/pib/ambientales/cuentas_ambientales/cuentasresiduos/Bt-Cuenta-residuos-2018p.pdf

DANE (2019). Boletín Técnico Gran Encuesta Integrada de Hogares GEIH. https://www.dane.gov.co/files/investigaciones/boletines/ech/ech/bol_empleo_ago_19.pdf

Devic, E., Leschen, W., Murray, F., \& Little, D. C. (2018). Growth performance, feed utilization and body composition of advanced nursing Nile tilapia (Oreochromis niloticus) fed diets containing BSF (Hermetia illucens) larvae meal. Aquaculture Nutrition, 24(1), 416-423. https://doi.org/10.1111/anu.12573

De Schutter, O. (2012). Agroecology, a Tool for the Realization of the Right to Food. In Agroecology and strategies for climate change (pp. 1-16). Springer, Dordrecht.

Dicke, M. (2018). Insects as feed and the Sustainable Development Goals. Journal of Insects as Food and Feed, 4(3), 147-156.

Dicke, M. (2019). Food and Business Global Challenges Programme. Final Report. Dutch Research Council (NWO). Netherlands. 21p.

Dicke, M. Aartsma, Y. \& K.B. Barragán-Fonseca. (2020). Protein transition in Colombia: Insects as feed in a circular agriculture. Report of Seed Money Project. https://edepot.wur.nl/545408

Durán-Izquierdo, J.C. (2019). Evaluación del uso de periphyton en Sistemas de Agro Acuicultura Integrada (SAAI) a pequeña escala en la Sierra Nevada de Santa Marta, Colombia. Master thesis, Universidad Nacional de Colombia - Sede Bogotá.

Durán Izquierdo, JC and Muñoz Ramírez, AP. (2016). Producción sostenible de alimentos mediante sistemas de agroacuicultura integrada. Memorias del VII Congreso Colombiano de Acuicultura, Revista Investigación Pecuaria. 
El-Naggar, G., Nasr-Alla, A., \& Kareem., R. O. (2008). Economic Analysis of Fish Farming in Behera Governorate of Egypt. Unpublished, (January). https://doi.org/10.13140/2.1.4794.5927.

Espinosa, N. (2004). Coca, coqueras y cocaleros: etnografía ilícita de la vida campesina en la Macarena. University of Antioquia.

Fajardo, D. (2014). Las guerras de la agricultura en Colombia 1980-2010. Bogotá. Colombia.

FAO (2010). Informe del Taller para el diagnóstico y seguimiento de la acuicultura de pequeña escala y recursos limitados en América Latina. Asunción, Paraguay, 18-20 de agosto de 2010. Serie Acuicultura en Latinoamérica, (3): $31 \mathrm{p}$.

FAO (2019). TAPE Tool for Agroecology Performance Evaluation 2019 - Process of development and guidelines for application. Test version. Rome: Food and Agriculture Organization of the United Nations.

FAO (2020a). Summary of the impacts of the COVID-19 pandemic on the fisheries and aquaculture sector: Addendum to the State of World Fisheries and Aquaculture 2020. Rome. https://doi.org/10.4060/ca9349en

FAO (2020b). How is COVID-19 Affecting the Fisheries and Aquaculture Food Systems. 7-11. https://doi.org/10.4060/ca8637en

FAO (2020c). The State of World Fisheries and Aquaculture 2020. Sustainability in action. Rome. https://doi.org/10.4060/ca9229en

FAO \& CEPAL (2020). Sistemas alimentarios y COVID-19 en América Latina y el Caribe: Hacia una pesca y acuicultura inclusiva, responsable y sostenible. Boletín N.¹5. Santiago, FAO. https://doi.org/10.4060/cb1197es

FEDEACUA (2015). Plan de negocios sectorial de la piscicultura colombiana. 413 p. https://fedeacua.org/files/plannegociopiscicola2015_1.pdf

Ferrer Llagostera, P., Kallas, Z., Reig, L., \& Amores de Gea, D. (2019). The use of insect meal as a sustainable feeding alternative in aquaculture: Current situation, Spanish consumers' perceptions and willingness to pay. Journal of Cleaner Production, 229, 10-21. https://doi.org/10.1016/j.jclepro.2019.05.012

Flores-Nava (2013). Diagnóstico de la Acuicultura de Recursos Limitados (AREL) y de la Acuicultura de la Micro y Pequeña Empresa (AMYPE) en América Latina. Serie Acuicultura en Latinoamérica, Número 7, diciembre 2012. FAO. http://www.fao.org/3/as235s/as235s.pdf

Flores-Nava, A. \& Estrada- Münzemayer, C. (2011). Diagnóstico de oportunidades de transferencia de tecnología en acuicultura y pesca continental en países de América del Sur. Serie Acuicultura en Latinoamérica, Número 2, enero 2010. FAO. http://www.fao.org/3/i2123s/i2123s00.pdfo

Forero-Álvarez, J. (2013). The Economy of Family Farming Production. Cuadernos de Desarrollo Rural, 10 (70), 27-45.

Foysal, M. J., Fotedar, R., Tay, C.-Y., \& Gupta, S. K. (2019). Dietary supplementation of BSF (Hermetica illucens) meal modulates gut microbiota, innate immune response and health status of marron (Cherax cainii, Austin 2002) fed poultry-by-product and fishmeal based diets. PeerJ, 7, e6891. https://doi.org/10.7717/peerj.6891

Francis, C., Lieblein, G., Gliessman, S., Breland, T.A., Creamer, N., Harwood, R., Salomonsson, L., Helenius, J., Rickerl, D., Salvador, R. \& Wiedenhoeft, M. (2003). Agroecology: The ecology of food systems. Journal of sustainable agriculture, 22(3), pp.99-118.

García, J. J., Celis, L. M., Villalba, E. L., C., L., Mendoza, Brú, S. B., \& Pardo, S. C. (2011). Evaluación del policultivo de bocachico Prochilodus magdalenae y tilapia Oreochromis niloticus utilizando superficies fijadoras de periphyton. Rev. Med. Vet. Zoot, 58(Ii), 71-83.

Gasco, L., Acuti, G., Bani, P., Dalle Zotte, A., Danieli, P. P., De Angelis, A., \& Roncarati, A. (2020). Insect and fish by-products as sustainable alternatives to conventional animal proteins in animal nutrition. Italian Journal of Animal Science, 19(1), 360-372.

Gliessman, S.R. (1998). Agroecology: ecological processes in sustainable agriculture. CRC press.

Gliessman, S.R. (2013). Agroecology: Growing the roots of resistance. Agroecology and sustainable food systems, 37(1), 19-31.

Gobierno de la República de Colombia (2019). Estrategia Nacional de Economía Circular.

Grain (2011). Food and Climate Change: the forgotten link. Against the Grain, September 2011.

Grupo de memoria histórica (2014). iBasta ya! Colombia: Memorias de guerra y dignidad. Bogotá: Imprenta nacional. Centro Nacional de Memoria Histórica. 2013.

Gutiérrez-Sanín, F. (2021). Tough Tradeoffs: Coca crops and agrarian alternatives in Colombia. International Journal of Drug Policy, 89, 103156. 
Henry, M., Gasco, L., Piccolo, G., \& Fountoulaki, E. (2015). Review on the use of insects in the diet of farmed fish: Past and future. Animal Feed Science and Technology, 203(1), 1-22.

https://doi.org/10.1016/j.anifeedsci.2015.03.001

HLPE (High Level Panel of Experts on Food Security and Nutrition) (2019). Agroecological and other innovative approaches for sustainable agriculture and food systems that enhance food security and nutrition (HLPE report 14). Roma: Committee on World Food Security. Retrieved from:

http://www.fao.org/fileadmin/user_upload/hlpe/hlpe_documents/HLPE_Reports/HLPE-Report14_EN.pdf

Hua, K.; Cobcroft, J.M.; Cole, A.; Condon, K.; Jerry, D.R.; Mangott, A.; Praeger, C.; Vucko, M.J. ; Zeng, C.; \& Zenger, K. (2019) The Future of Aquatic Protein: Implications for Protein Sources in Aquaculture Diets. One Earth, 1, 316-329.

IDEAM (2018). Informe Nacional de Residuos o Desechos Peligrosos en Colombia 2017. Bogotá, DC. http://documentacion.ideam.gov.co/openbiblio/bvirtual/023849/Informe_RESPEL_2017.pdf

IPES-Food (International Panel of Experts on Sustainable Food Systems) (2018). Breaking away from industrial food and farming systems. Seven case studies of agroecological transition. http://www.ipes-food.org/_img/upload/files/CS2_web.pdf

Ites, S., Smetana, S., Toepfl, S., \& Heinz, V. (2020). Modularity of insect production and processing as a path to efficient and sustainable food waste treatment. Journal of Cleaner Production, 248, 119248.

Jackson, W. (2002). Natural systems agriculture: a truly radical alternative. Agriculture, ecosystems \& environment, 88(2), pp.111-117.

Joyce, A., \& Paquin, R. L. (2016). The triple layered business model canvas: A tool to design more sustainable business models. Journal of Cleaner Production, 135, 1474-1486. https://doi.org/10.1016/j.jclepro.2016.06.067

Jurgilevich, A., Birge, T., Kentala-Lehtonen, J., Korhonen-Kurki, K., Pietikäinen, J., Saikku, L., \& Schösler, H. (2016). Transition towards circular economy in the food system. Sustainability, 8(1), 69.

Kaza, S.; Yao, L.C.; Bhada-Tata, P.; Van Woerden, F. (2018). What a Waste 2.0: A Global Snapshot of Solid Waste Management to 2050. Urban Development. Washington, DC: World Bank. (C) World Bank. https://openknowledge.worldbank.org/handle/10986/30317 License: CC BY 3.0 IGO

Koeleman, E. (2016). Insect meal allowance expected in 2020. All About Feed. https://www.allaboutfeed.net/all-about/new-proteins/insect-meal-allowance-expected-in-2020/

Kojima, R. \& Ishikawa, M. (2013). Prevention and Recycling of Food Wastes in Japan. Policies and Achievements. Resilient Cities, 4598 th Global Forum on Urban Resilience \& Adaptation, May 31st-June 2nd 599, Bonn, Germany. (Poster).

LeGrand, C. (2016). Colonización y protesta campesina en Colombia (1850-1950). Ediciones Uniandes-Universidad de los Andes.

Locke, J. (2015). The second treatise of civil government. Broadview Press.

Machado, A. (2017). El problema de la tierra: conflicto y desarrollo en Colombia. Debate. Bogotá, Colombia.

Madau, F. A., Arru, B., Furesi, R., \& Pulina, P. (2020). Insect farming for feed and food production from a circular business model perspective. Sustainability, 12(13), 5418.

MADR (2021). Dirección de Cadenas Pecuarias, Pesqueras y Acuícolas. Cadena de la Acuicultura. https://sioc.minagricultura.gov.co/Acuicultura/Documentos/2020-1230\%20Cifras\%20Sectoriales.pdf

Magalhães, R., Sánchez-López, A., Leal, R. S., Martínez-Llorens, S., Oliva-Teles, A., \& Peres, H. (2017). BSF (Hermetia illucens) pre-pupae meal as a fish meal replacement in diets for European seabass (Dicentrarchus labrax). Aquaculture, 476(April), 79-85. https://doi.org/10.1016/j.aquaculture.2017.04.021

Mejía, C. (2019). Análisis de la implementación de la resolución 970 del 2010 sobre el derecho a la alimentación de los campesinos de Colombia. Bachelor thesis. Javeriana University.

Minagricultura (28 october, 2016). El 83.5\% de los alimentos que consumen los colombianos son producidos por nuestros campesinos. Ministerio de Agricultura y Desarrollo Rural. https://www.minagricultura.gov.co/noticias/Paginas/El-83-de-los-alimentos-que-consumen-loscolombianos-son-producidos-por-nuestros-campesinos.aspx 
Mojica B, H, O. M, A. Landínes P y David F. Rivas S (Eds) (2018), Fundamentos de Innovación En Fundamentos de innovación Tecnológica en Acuicultura Intensiva. Oficina de Generación del Conocimiento y la Información, Autoridad Nacional de Acuicultura y Pesca AUNAP (C), $265 \mathrm{p}$

Moreno, Y. M. (2013). Estado del arte del conocimiento sobre periphyton en Colombia. Revista Gestión y Ambiente, 16(3), 91-117.

Movement Generation (2016). From Banks and Tanks to Cooperation and Caring. A Strategic Framework for a Just Transition. https://movementgeneration.org/wpcontent/uploads/2016/11/JT_booklet_English_SPREADs_web.pdf

Muñoz-Ramírez, A.P., Zambrano-Navarrete, J.A., Rodríguez-Velásquez, L., Landines-Parra, M.A. (2020). Memorias: Foro "COVID-19 ¿Oportunidad para reinventar la acuicultura colombiana?". $18 \mathrm{p}$. http://medicinaveterinariaydezootecnia.bogota.unal.edu.co/fileadmin/user_upload/MemoriasSesio n2ForoAcuicola.pdf

Muscio, A., \& Sisto, R. (2020). Are agri-food systems really switching to a circular economy model? Implications for European research and innovation policy. Sustainability, 12(14), 5554.

Naef, P. (2018). "Narco-heritage" and the Touristification of the Drug Lord Pablo Escobar in Medellin, Colombia. Journal of Anthropological Research, 74(4), 485-502.

Olasunkanmi, J. B. (2012). Economic Analysis of Fish Farming in Osun State, South-Western Nigeria. IIFET Tanzania Proceedings, 1-11.

United Nations (UN). 2018. Perspectiva de la Gestión de Residuos en América Latina y el Caribe. Available from: https://www.unep.org/es/resources/informe/perspectiva-de-la-gestion-deresiduos-en-america-latina-y-el-caribe

Poole N. (2017) Smallholder Agriculture and Market Participation. Rome: FAO and Practical Action Publishing; 2017 http://dx.doi.org/ 10.3362/9781780449401. 210 pp.

Payne, C. L. R., Scarborough, P., Rayner, M., \& Nonaka, K. (2016). Are edible insects more or less 'healthy' than commonly consumed meats? A comparison using two nutrient profiling models developed to combat over-and undernutrition. European journal of clinical nutrition, 70(3), 285291.

Petersen, P., Silveira, L., Bianconi-Fernandes, G., \& Gomes de Almeida, S. (2020). Lume: A method for the economic-ecological evaluation of agroecosystems. Coventry: Centre for Agroecology, Water and Resilience.

Pfister, S. \& Bayer, P. (2014). Monthly water stress: spatially and temporally explicit consumptive water footprint of global crop production. J. Clean. Prod. 73, 52e62. http://dx.doi.org/10.1016/j.jclepro.2013.11.031.

Presidencia de la República de Colombia (2019). Presidente Duque lanzó Estrategia Nacional de Economía Circular, primera política ambiental de este tipo en América Latina. https://id.presidencia.gov.co/Paginas/prensa/2019/190614-Presidente-Duque-EstrategiaNacional-Economia-Circular-primera-politica-ambiental-de-este-tipo-en-AmericaLatina.aspx\# : :text=La\%20Estrategia\%20Nacional\%20de\%20Econom\%C3\%ADa\%20Circular\%2 Otransformar\%C3\%A1\%20las\%20cadenas\%20de,Am\%C3\%A9rica\%20Latina\%20para\%20el\%202 030.

Rana, K. J., Siriwardena, S., \& Hasan, M. R. (2009). Impact of rising feed ingredient prices on aquafeeds and aquaculture production. FAO Fisheries and Aquaculture Technical Paper (Vol. 541).

Ravi, H. K., Vian, M. A., Tao, Y., Degrou, A., Costil, J., Trespeuch, C., \& Chemat, F. (2019). Alternative solvents for lipid extraction and their effect on protein quality in black soldier fly (Hermetia illucens) larvae. Journal of Cleaner Production, 238, 117861.

Raworth, K. (2017). Doughut economics. Seven ways to think like a 21st-century economist. Random House Business Books, London, UK, 373 pp.

Ritchie, H., \& Roser, M. (2017). Meat and dairy production. Our World in Data. https://ourworldindata.org/meat-production (accessed on 1 March 2021).

Rockström J, et al. (2009). A safe operating space for humanity. Nature 461, 472-475

Rojas-Sotelo, M. L. (2014). Narcoaesthetics in Colombia, Mexico, and the United States: Death Narco, Narco Nations, Border States, Narcochingadazo?. Latin American Perspectives, 41(2), 215-231.

Sanín, F. G. (2015). ¿Una historia simple?. En: Comisión Histórica del Conflicto y sus Víctimas (Editores), Contribución al entendimiento del conflicto armado en Colombia. Colombia: Centro Nacional de Memoria Histórica. 
Scott, J. C. (1977). The moral economy of the peasant: Rebellion and subsistence in Southeast Asia (Vol. 315). Yale University Press.

Sealey, W., Gibson Gaylord, T., Barrows, F. T., Tomberlin, J. K., McGuire, M. A., Ross, C., \& St-Hilaire, S. (2011). Sensory Analysis of Rainbow Trout, Oncorhynchus mykiss,Fed Enriched BSF Prepupae, Hermetia illucens. Journal of the World Aquaculture Society, 42, 72-81. https://doi.org/https://doi.org/10.1111/j.1749-7345.2010.00441.x

Smetana, S., Schmitt, E., \& Mathys, A. (2019). Sustainable use of Hermetia illucens insect biomass for feed and food: Attributional and consequential life cycle assessment. Resources, Conservation and Recycling, 144 (August 2018), 285-296. https://doi.org/10.1016/j.resconrec.2019.01.042

Smetana, S., Palanisamy, M., Mathys, A., \& Heinz, V. (2016). Sustainability of insect use for feed and food: Life Cycle Assessment perspective. Journal of Cleaner Production, 137, 741-751.

Sogari, G., Amato, M., Biasato, I., Chiesa, S., \& Gasco, L. (2019). The potential role of insects as feed: A multi-perspective review. Animals, 9(4), 119.

Solano, V. (2012). Documental 970, la tragedia que vivieron los arroceros de campoalegre (Huila) [Película]. https://www.youtube.com/watch?v=z_nwWgGfB8\&ab_channel=teleSURtv

SSPD - Superintendencia de Servicios Públicos Domiciliarios (2018). Sistema de Gestión Documental ORFEO. Informe Nacional de Aprovechamiento de 2017.

https://www.superservicios.gov.co/sites/default/archivos/Publicaciones/Publicaciones2018/Dic/3._ informe_nacional_de_aprovechamiento_2017.pdf

Steinfeld, H., Gerber, P., Wassenaar, T., Castel, V., Rosales, M., \& De Haan, C. (2006). Livestock's Long Shadow. Environmental Issues and Options. Food and Agriculture Organization of the United Nations (FAO), Rome.

Thompson, F. L., Abreu, P. C., \& Wasielesky, W. (2002). Importance of biofilm for water quality and nourishment in intensive shrimp culture. Aquaculture, 203(304), 263-278. http://doi.org/10.1016/S0044-8486(01)00642-1.

Thorarinsdottir, R. I., Jokumsen, A., Bjornsson, B. T., \& Torrissen, O. (2011). Local raw materials for production of fish feed for aquaculture. (February 2015), 66.

http://www.nordicinnovation.org/Global/_Publications/Reports/2011/2011_lokal_raw_material_fis h_feed_rep.pdf

Tittonell, P. (2020). Assessing resilience and adaptability in agroecological transitions. Agricultural Systems, 184, 102862.

Toledo, V. M. (1990). The ecological rationality of peasant production. The ecological rationality of peasant production, 53-60.

Uddin, M. S., Azim, M. E., Wahab, M. A., \& Verdegem, M. C. J. (2009). Effects of substrate addition and supplemental feeding on plankton composition and production in tilapia (Oreochromis niloticus) and freshwater prawn (Macrobrachium rosenbergii) polyculture. Aquaculture, 297(1-4), 99-105. http://doi.org/10.1016/j.aquaculture.2009.09.016

Van der Ploeg, J. D. (2008). The new peasantries: struggles for autonomy and sustainability in an era of empire and globalization. Routledge. The Netherlands.

Van Huis A., Van Itterbeeck J., Klunder H., Mertens E., Halloran A., Muir G., \& Vantomme P. (2013). Edible insects: Future prospects for food and feed security. Rome, Italy: Food and Agriculture Organization of the United Nations (FAO). $201 \mathrm{pp}$.

Van Huis A. (2020). Insects as food and feed, a new emerging agricultural sector: a review. J Insects Food Feed 6, 27-44.

Voltolina, D., Audelo-Naranjo, J. M., Romero-Beltrán, E., Pacheco-Marges, M. del R., \& LópezValenzuela, L. (2013). Promoción del periphyton para el cultivo de camarón blanco: hacia una acuicultura ecológica. Boletim Do Instituto de Pesca, 39(2), 179-186.

Wezel, A., Bellon, S., Doré, T., Francis, C., Vallod, D. and David, C. (2009). Agroecology as a science, a movement and a practice. A review. Agronomy for sustainable development, 29(4), 503-515.

World Bank (2021, May 15). Población rural (\% de la población total) - Colombia. https://datos.bancomundial.org/indicador/SP.RUR.TOTL.ZS. 


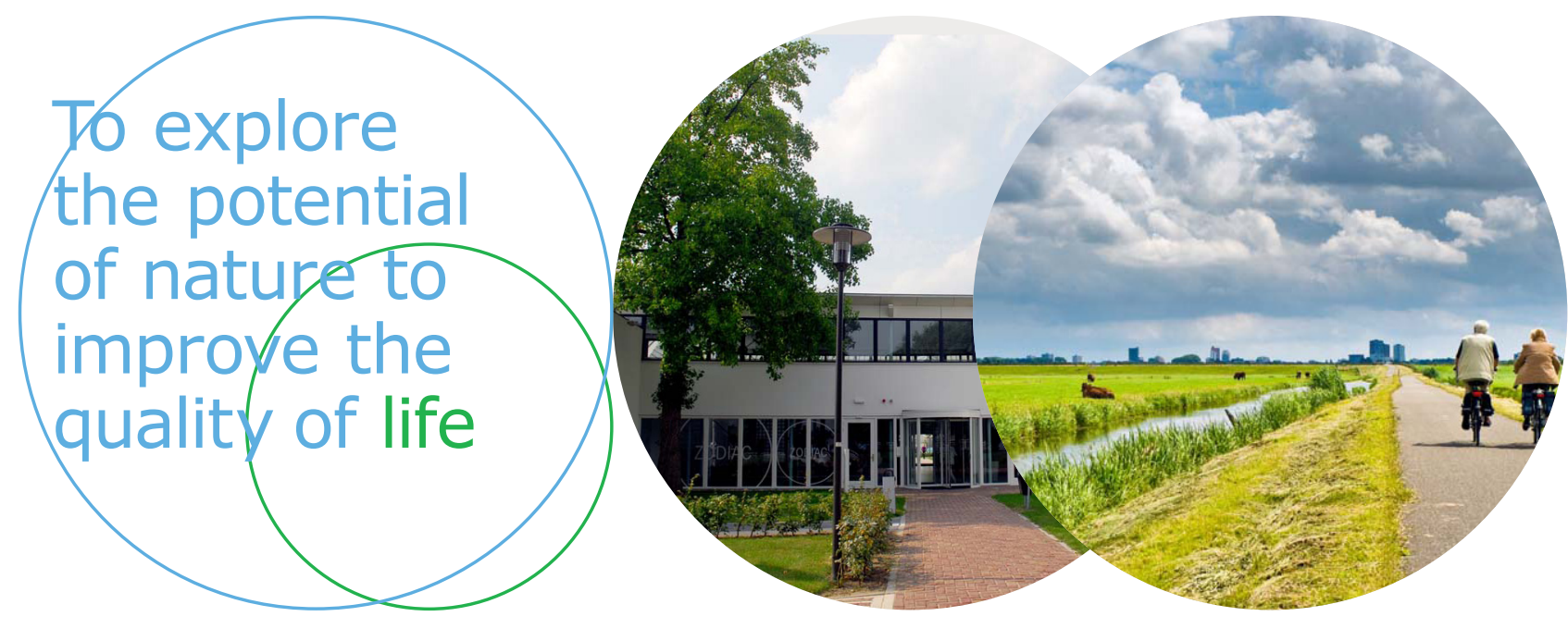

Wageningen Livestock Research P.O. Box 338

6700 AH Wageningen

The Netherlands

$\mathrm{T}+31(0) 317483953$

E info.livestockresearch@wur.nl

www.wur.nl/livestock-research

Wageningen Livestock Research creates science based solutions for a sustainable and profitable livestock sector. Together with our clients, we integrate scientific knowledge and practical experience to develop livestock concepts for future generations.

Wageningen Livestock Research is part of Wageningen University \& Research. Together we work on the mission: 'To explore the potential of nature to improve the quality of life'. A staff of 6,500 and 10,000 students from over 100 countries are working worldwide in the domain of healthy food and living environment for governments and the business community-at-large. The strength of Wageningen University \& Research lies in its ability to join the forces of specialised research institutes and the university. It also lies in the combined efforts of the various fields of natural and social sciences. This union of expertise leads to scientific breakthroughs that can quickly be put into practice and be incorporated into education. This is the Wageningen Approach. 